\title{
15-Öğrenci yapısı podcast (ses yayını) oluşturma süreçlerinin yabancı dil olarak Türkçe öğrenenlerin konușma ve yazma becerisi ile bu becerilerdeki öz yeterliliklerine etkisi ${ }^{1}$
}

\section{Osman Kürşat YORGANCI²}

Bayram BAŞ3

\begin{abstract}
APA: Yogancı, O. K. \& Baş, B. (2022). Öğrenci yapısı podcast (ses yayını) oluşturma süreçlerinin yabancı dil olarak Türkçe öğrenenlerin konuşma ve yazma becerisi ile bu becerilerdeki öz yeterliliklerine etkisi. RumeliDE Dil ve Edebiyat Araştırmaları Dergisi, (26), 256-282. DOI: 10.29000/rumelide.1073907.
\end{abstract}

\section{$\ddot{O} \mathbf{z}$}

Bu araştırmanın amacı, öğrenci yapısı podcast (ses yayını) oluşturma süreçlerinin yabancı dil olarak Türkçe öğrenenlerin konuşma ve yazma becerileri ile bu becerilerdeki öz yeterliliklerine etkisini araştırmaktır. Çalışma nicel araştırma yöntemlerinden eşleştirilmiş ön test son test deney ve kontrol gruplu yarı deneysel desenle yürütülmüştür. Çalışma grubu 2019-2020 eğitim-öğretim yılında Yıldız Teknik Üniversitesi Türkçe ve Yabancı Dil Uygulama ve Araştırma Merkezi (TÖMER)'nde B1 seviyesinde yabancı dil olarak Türkçe öğrenen 40 öğrenciden oluşmaktadır. Çalışmada veri toplama aracı olarak araştırmacı tarafından geliştirilen "Kişisel Bilgi Formu”, “Orta (B1-Bağımsız) Düzey Bağımsız Konuşma Türkçe Yeterlilik Sınavı”, “Orta (B1-Bağımsız) Düzey Karşılıklı Konuşma Türkçe Yeterlilik Sınavı”, “Orta (B1- Bağımsız) Düzey Yazma Türkçe Yeterlilik Sınavı”, "Yabancı Dil Olarak Türkçe Öğrenenler İçin B 1 Düzeyi Bağımsız Konuşma Becerisi Dereceli Puanlama Anahtarı”, "Yabancı Dil Olarak Türkçe Öğrenenler İçin B1 Düzeyi Karşılıklı Konuşma Becerisi Dereceli Puanlama Anahtarı" ve "Yabancı Dil Olarak Türkçe Öğrenenler İçin B1 Düzeyi Yazma Becerisi Dereceli Puanlama Anahtarı" kullanılmıştır. Ayrıca ilgililerden izinleri alınan "Konuşma Öz Yeterlik Ölçeği” ve "Yazma Öz Yeterlik Ölçeği” de çalışmada veri toplama aracı olarak kullanılmıştır. Çalışma sonucunda Türkçenin yabancı dil olarak öğretiminde öğrenci yapısı sesli yayın oluşturma süreçlerine katılan deney grubu öğrencilerinin konuşma ve yazma başarı puanları ile konuşma ve yazma öz yeterlilik düzeylerinin arttığı sonucuna ulaşılmıştır. Ortaya çıkan bu anlamlı farklılık sebebiyle Türkçenin yabancı dil olarak öğretiminde podcast kullanımının konuşma ve yazma becerisi ile konuşma ve yazma öz yeterliliklerini geliştirmede yenilikçi bir teknolojik öğretim aracı olabileceği düşünülmektedir.

Anahtar kelimeler: Ses yayını, konuşma ve yazma becerisi, konuşma ve yazma öz yeterliliği

Bu makale ikinci yazar danışmanlığında yürütülen "Yabancı Dil Olarak Türkçe Öğretiminde Podcast (Ses Yayını) Kullanımının Üretici Dil Becerilerine Etkisi” isimli doktora tez çalışması verileri kullanılarak birinci yazar tarafından üretilmiştir.

2 Öğr. Gör. Dr., Yıldız Teknik Üniversitesi, Rektörlük, TÖMER (İstanbul, Türkiye), yorganci@yildiz.edu.tr, ORCID ID: oooo-0001-8230-219X [Araştırma makalesi, Makale kayıt tarihi: 21.01.2022-kabul tarihi: 20.02.2022; DOI: 10.29000/rumelide.1073907]

3 Prof. Dr., Yıldız Teknik Üniversitesi, Eğitim Fakültesi, Türkçe ve Sosyal Bilimler Eğitimi Bölümü, Türkçe Eğitimi ABD (İstanbul, Türkiye), bayrambas@gmail.com, ORCID ID: 00oo-0003-3569-9395

Adres $\mid$ Address

RumeliDE Dil ve Edebiyat Araştrmalarn Dergisi Osmană̆a Mahallesi, Mürver Ciceği Sokak, No:14/8 Kadıköy - İSTANBUL / TÜRKIYE 34714 e-posta: editor@rumelide.com

RumeliDE Journal of Language and Literature Studies Osmanağa Mahallesi, Mürver Çiçeği Sokak, No:14/8

Kadıköy - ISTANBUL / TURKEY 34714 tel: +90 505 7958124, +90 2167730616

e-mail: editor@rumelide.com,

phone: +90 505 7958124, +90 2167730616 


\title{
The impact of student - generated podcast formation processes on speaking and writing skills of learners of Turkish as a foreign language and their self-efficacy in these skills
}

\begin{abstract}
The aim of this study is to investigate the impact of the student-generated podcast formation processes on speaking and writing skills learners of Turkish as a foreign language and their selfefficacy in these skills. The study was carried out with a paired sample test for pre-test and post-test experimental and control groups of a quasi-experimental design, which is one of the quantitative research methods. The study group consists of 40 students who learn Turkish as a foreign language at B1 level at Yıldız Technical University Turkish and Turkish and Foreign Languages Application and Research Center (TÖMER) in the 2019-2020 academic year. "Personal Information Form", "Intermediate (B1-Independent) Level Turkish Proficiency Exam for Speaking", "Intermediate (B1Independent) Level Turkish Proficiency Exam for Conversation", "Intermediate (B1-Independent) Level Turkish Proficiency Exam for Writing”, "B1 Level Independent Speaking Skill Rubric for Learners of Turkish as a Foreign Language", "B1 Level Conversation Rubric for Learners of Turkish as a Foreign Language" and "B1 Level Writing Skill Rubric for Learners of Turkish as a Foreign Language" were used, developed by the researcher, as data collection tool in the study. In addition, "Speaking Self-Efficacy Scale" and "Writing Self-Efficacy Scale", which were approved by the authorities, were also used as data collection tools in the study. As a result of the study, it was figured out that the speaking and writing success rates and speaking and writing self-efficacy levels of the experimental group student, who participated in the student-generated audio broadcasting processes in teaching Turkish as a foreign language, increased. Due to this significant difference, it is considered that the use of podcasts can be an innovative technological teaching tool for improving speaking and writing skills and speaking and writing self-efficacy in teaching Turkish as a foreign language.
\end{abstract}

Keywords: Pocasting, speaking and writing skill, speaking and writing self-efficacy

\section{Giriş}

Teknolojinin hızlı gelişiminin içerisinde bulunduğumuz zaman diliminde iletişimi önceki dönemlere göre daha çok etkilediği ve değiştirdiği inkâr edilemez bir gerçektir. 21. yüzylldaki bu gelişmeler insanların özel hayatlarından eğitim yaşamlarına, meslek hayatlarından kamusal yaşam alanlarına kadar köklü değişikliklere sebep olmuş ve olmaya devam etmektedir. New London Group (1996)'a göre bu önemli etki, 21. yüzyılın son yıllarında insan yaşamını şekillendirecek karakteristik özellik olacaktır.

ABD’de gerçekleştirilen “21. Yüzyll Öğrenme Ortaklığ1 Projesi (P21-Partnership for 21st Century Learning)" adlı çalışmada "21. Yüzyl Becerileri (Partnership for 21st Century Skills)” başlı̆̆ altında sayılan 21. yüzyıl insanından beklenen becerilerin neredeyse tamamına yakınının eğitim, teknoloji ve dille doğrudan veya dolaylı olarak ilişkili olduğu dikkat çekmektedir (Battleforkids, 2019; OECD, 2021).

Foulger ve diğerleri (2017)'nin Amerikan Eğitim Bakanlığı Eğitim Teknolojileri Ofisi'nin öğretmen yetiştiricilerinin teknoloji yeterliliklerinin belirlenmesi çağrısı üzerine gerçekleştirdikleri "Öğretmen Eğiticilerinin Teknoloji Yeterlilikleri” isimli çalışmada ABD Ulusal Eğitim Teknolojisi Planı çerçevesinde öğretmen yetiştiricilerinin teknoloji yeterliliklerinin oluşturulmaya çalışlldığı görülmektedir.

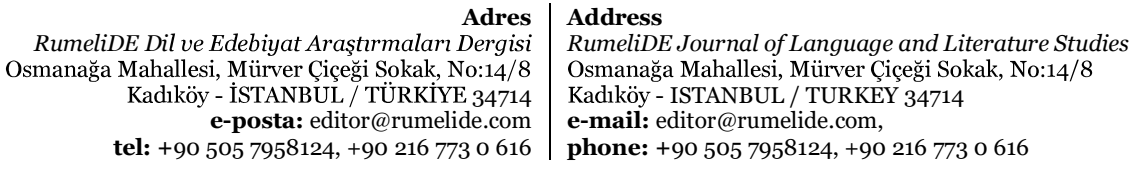


The impact of student - generated podcast formation processes on speaking and writing skills of learners of Turkish as a foreign language and their self-efficacy in these skills / O. K. Yorganc1 \& B. Baş (pp. 256-282)

Öğretmen eğiticilerinin teknolojik yeterliliklerini belirlemeyi amaçlayan ilgili çalışmadan da anlaşılabileceği gibi günümüz eğitim ortamlarının teknolojiden bağımsız düşünülmesi mümkün görünmemektedir.

2019’da yaynnlanan “Becerilerin Görünümü 2019: Dijital Dünyaya Doğru Gelişim (Toker ve diğ., 2021, 3-6)." isimli raporda, "Avrupa Vatandaşları Dijital Yeterlilikler Çerçevesi” ile "Eğitimciler için Dijital Yeterlilikler Çerçevesi”nde dijital dünyaya doğru hızlı bir yönelimin söz konusu olduğu günümüzde eğitime ve eğitimin temel taşıyıcısı dile vurgu yapıldığı, iletişimin ve dilin teknolojiden bağımsız düşünülemeyeceğinin altının çizildiği dikkat çekmektedir

Türkiye Yeterlilikler Çerçevesi (TYÇ, 2015)'nde bireyin kazanmasının beklenildiği hayat boyu öğrenme becerileri kapsamında matematiksel yetkinlik ve bilim/teknolojide temel yetkinlikler ile dijital yetkinlik şeklinde sayılan anahtar kavramlar arasında ana dilinde iletişim ve yabancı dillerde iletişime birinci ve ikinci sıralarda yer verilmiş olması eğitimde dil ve yabancı dil eğitiminin önemine açıça dikkat çekildiğini göstermektedir.

Teknolojinin insan yaşamının tamamında, özelikle eğitimde ve dil eğitiminde önemli düzeyde yer aldı̆̆ günümüzde Türkçenin yabancı dil olarak öğretimi süreçlerinin de günün gerekleri ve ihtiyaçlarına göre yeniden şekillendirilmesi gerekmektedir. Yabancı dil olarak Türkçe öğretimi süreçlerine yenilikçi teknolojik eğitim ve öğretim açlarının dâhil edilmesi gerekmektedir.

Küreselleşen dünyaya uyum sağlayabilmek için eğitim ortamlarının gerekli teknolojilerle donatılması gerekmektedir. Türkçenin yabancı dil olarak öğretiminde, özellikle de yazma ve konuşma becerilerinde çağın gereklerine uygun yenilikçi teknolojik araçlarla öğretim yapılması hâlinde dil eğitiminde istenilen ve beklenilen seviyelere daha kolay ulaşlabileceğini unutmamak gerekmektedir.

Yabancı dil olarak Türkçe öğretiminde kullanılabilecek yenilikçi teknolojik araçlardan biri de dil eğitiminde kullanımı bakımından "öğrenci yapısı/üretimi (student generated/created)" ve "öğretmen yapısı/üretimi (teacher generated/created)" şeklinde ikiye ayrılan podcastlerdir (ses yayınları) (Koçak, 2017; Kooten, Bia, 2019).

Ses yayını, ipod (mp3 oynatıcısı) sözcüğünün "pod” bölümü ile İngilizcede yayın anlamına gelen broadcast sözcüğünün "cast” bölümünün birleşmesiyle oluşmuş genel olarak RSS tekniğiyle taşınabilir cihazlara dağıtımı sağlanabilen bir çeşit ses içeriği; yabancı dil öğrenimi için hazırlanmış, öğrencilerin yeni bir dil öğrenmesini kolaylaştıran yapılandırılmış ses kayıtları ve RSS teknolojileri kullanılarak bilgisayar ve taşınabilir cihazlara uygun teknolojiler yardımıyla indirilebilen işitsel malzemeler olarak çeşitli ve farklı biçimlerde tanımlanmaktadır (Cayhan, Karakaş, 2019; Şendağ ve diğ., 2017).

Literatür tarandığında yabancı dil olarak Türkçe öğretiminde ses yayınları üzerine yok denecek kadar az çalışmanın bulunduğu, var olan çalışmaların da daha çok öğretmen yapısı ses yayınları ve genellikle dinleme becerisi üzerine yoğunlaştığı görülmektedir. Bununla birlikte yabancı dillerde öğrenci yapısı ses yayını araştırmalarına ve bu yayınların konuşma becerisi üzerindeki etkileri üzerine incelemeler yapıldığına rastlanılsa da Türkçenin yabancı dil olarak öğretiminde öğrenci yapısı ses yayınları ile bunların konuşma ve yazma becerileri üzerindeki etkilerine değinen araştırmalara rastlanılmamaktadır.

Bu bakımdan öğrenci yapısı podcast (ses yayını) kullanımının yabancı dil olarak Türkçe öğretiminde Türkçeyi yabancı dil olarak öğrenenlerin konuşma ve yazma becerisi başarıları ile konuşma ve yazma öz yeterlilik algıları üzerine etkileri araştırılmaya değer görülmüştür.

Adres | Address

RumeliDE Dil ve Edebiyat Araşturmalarn Dergisi $\quad$ RumeliDE Journal of Language and Literature Studies Osmanağa Mahallesi, Mürver Çiçeği Sokak, No:14/8 Osmanağa Mahallesi, Mürver Çiçeği Sokak, No:14/8

Kadıköy - İSTANBUL / TÜRKIYY 34714 Kadıköy - ISTANBUL / TURKEY 34714 e-posta: editor@rumelide.com e-mail: editor@rumelide.com,

tel: +90 505 7958124, +90 2167730616 phone: +90 505 7958124, +90 2167730616 


\section{Yöntem}

Bu bölümde araştırmanın modeli, çalışma grubu, veri toplama araçları ile verilerin toplanması ve analizi açılanmıştır.

\section{Arașturmanın modeli}

Nicel araştırma işlemlerinin uygulandığı araştırma eşleştirilmiş ön test-son test kontrol gruplu yarı deneysel desen ile gerçekleştirilmiştir. Değişkenler arasındaki sebep-sonuç ilişkilerini belirlemeyi hedefleyen araştırma desenleri deneysel desenler olarak isimlendirilmektedir. $\mathrm{Bu}$ amacı gerçekleştirmek için bağımsız değişkenleri manipüle ederken iç geçerliliği korumak adına dışsal değişkenleri kontrol altına alıp bağımlı değişkenler üzerinde ölçme yapmak gerekmektedir. Deneysel desenler deney ve kontrol gruplarına atanmış deneklerin deney öncesi ve sonrası ölçüldüğü desenler olarak da tanımlanabilir (Büyüköztürk, 2008).

\section{Çalışma grubu}

Araştırma 2019-2020 eğitim-öğretim yılında Yıldız Teknik Üniversitesi Türkçe ve Yabancı Dil Uygulama ve Araştırma Merkezi'nde B1 düzeyinde Türkçe öğrenen 40 öğrenci ile gerçekleştirilmiştir. Deney ve kontrol gruplarına birbirine en çok benzeyen öğrencilerden atama yapılabilmesi için çalışmaya konu olan kişi veya nesneleri belirli özelliklerine göre sınıflandırmaya yarayan ve çok değişkenli bir analiz olan kümeleme analizi kullanılmıştır (Antalyalı, 2006, s. 349).

B1 düzeyindeki 40 öğrencinin kümeleme analizi ile deney ve kontrol gruplarına atamalarının yapılabilmesi için ön ve son testlerde kullanılmak üzere araştırmacı tarafından geliştirilen konuşma ve yazma becerisi yeterlilik sınavlarına alınmayacak maddelerden oluşturulan bağımsız bir sınav uygulanmıştır. Ayrıca öğrencilerin demografik özelliklerine yönelik bilgiler elde etmek üzere yine araştırmacı tarafından geliştirilen bir Kişisel Bilgi Toplama Formu kullanılmıştır.

Beceri sınavlarından elde edilen puanlara uygulanan Kendall Testi ve dağıtım korelasyonu sonrası yirmişer öğrencilik deney ve kontrol grubu oluşturulmuştur.

Deney ve kontrol grubunu oluşturan öğrencilerin demografik özellikleri Tablo 1'de gösterilmiştir.

Tablo 1: Deney ve kontrol grubu özellikleri

\begin{tabular}{llc} 
& Kadın & Erkek \\
\hline Deney & 9 & 11 \\
Kontrol & 7 & 13 \\
Toplam & 16 & 24 \\
\hline
\end{tabular}

\section{Veri toplama araçları}

Araştırmada veri toplama aracı olarak "Orta (B1-Bağımsız) Düzey Bağımsız Konuşma Türkçe Yeterlilik Sınavı, Orta (B1-Bağımsız) Düzey Karşılıklı Konuşma Türkçe Yeterlilik Sınavı, Orta (B1-Bağımsız) Düzey Türkçe Yazma Yeterlilik Sınavı, Yabancı Dil Olarak Türkçe Öğrenenler İçin B1 Düzeyi Bağımsız Konuşma Becerisi Dereceli Puanlama Anahtarı, Yabancı Dil Olarak Türkçe Öğrenenler İçin B1 Düzeyi

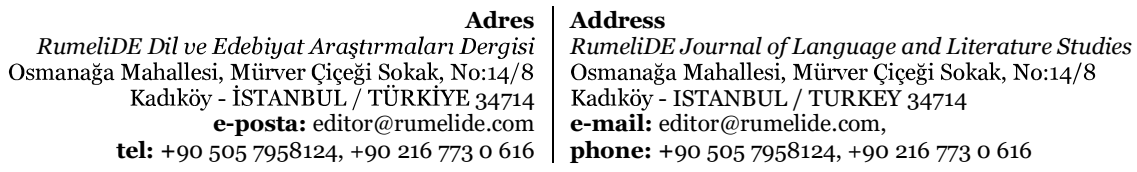


The impact of student - generated podcast formation processes on speaking and writing skills of learners of Turkish as a foreign language and their self-efficacy in these skills / O. K. Yorganc1 \& B. Baş (pp. 256-282)

Karşılıklı Konuşma Becerisi Dereceli Puanlama Anahtarı, Yabancı Dil Olarak Türkçe Öğrenenler İçin B1 Düzeyi Yazma Becerisi Dereceli Puanlama Anahtarı ile Konuşma Öz Yeterlik Ölçeği ve Yazma Öz Yeterlik Ölçeği” kullanılmıştır.

B1 düzeyi bağımsız konuşma beceri sınavının hazırlanması için B1 seviyesi bağımsız konuşma yeterliliklerinin gösterildiği bir belirtke tablosu oluşturulmuş, belirtke tablosuna göre beceri sinavinın madde havuzu hazırlanmış, hazırlanan madde havuzu kapsam geçerliliği için uzman görüşlerine sunulmuş, beş farklı alan uzmanından havuzdaki dört maddenin her biri için 1 (en yüksek) ila 4 (en düşük) arasında sıralı puanlama yapması istenmiş, uzman görüşlerine göre en yüksek toplam puanı alan maddenin ön-son test beceri sınavı olarak kullanılmasına karar verilmiştir.

Tablo 2: Orta (B1-Bağımsız) düzey bağımsız konuşma Türkçe yeterlilik sınavı uzman görüşleri

\begin{tabular}{lllllll}
\hline & P1 & P2 & P3 & P4 & P5 & $\begin{array}{l}\text { Toplam } \\
\text { Puan }\end{array}$ \\
\hline M1 & 4 & 3 & 4 & 4 & 4 & 19 \\
M2 & 1 & 1 & 1 & 1 & 1 & 5 \\
M3 & 2 & 2 & 3 & 2 & 3 & 12 \\
M4 & 3 & 4 & 2 & 3 & 2 & 14 \\
\hline
\end{tabular}

Uzman görüşlerine göre en yüksek puanı alan M1 ön-son test bağımsız konuşma becerisi sınav sorusu olarak kullanılmıştır.

B1 düzeyi karşılıklı konuşma beceri sınavının hazırlanması için B1 seviyesi karşılıklı konuşma yeterliliklerinin gösterildiği bir belirtke tablosu oluşturulmuş, belirtke tablosuna göre beceri sinavının madde havuzu hazırlanmış, hazırlanan madde havuzu kapsam geçerliliği için uzman görüşlerine sunulmuş, beş farklı alan uzmanından havuzdaki dört maddenin her biri için 1 (en yüksek) ila 4 (en düşük) arasında sıralı puanlama yapması istenmiş, uzman görüşlerine göre en yüksek toplam puanı alan maddenin ön-son test beceri sınavı olarak kullanılmasına karar verilmiştir.

Tablo 3: Orta (B1-Bağımsız) düzey karşılıklı konuşma Türkçe yeterlilik sınavı uzman görüşleri

\begin{tabular}{lllllll}
\hline & P1 & P2 & P3 & P4 & P5 & $\begin{array}{l}\text { Toplam } \\
\text { Puan }\end{array}$ \\
\hline M1 & 4 & 4 & 4 & 4 & 4 & 20 \\
M2 & 3 & 3 & 3 & 3 & 3 & 15 \\
M3 & 2 & 2 & 1 & 1 & 2 & 8 \\
M4 & 1 & 1 & 2 & 2 & 1 & 7 \\
\hline
\end{tabular}

Uzman görüşlerine göre en yüksek puanı alan M1 ön-son test karşılıklı konuşma becerisi sınav sorusu olarak kullanılmıştır.

B1 düzeyi yazma konuşma beceri sınavının hazırlanması için B1 seviyesi yazma yeterliliklerinin gösterildiği bir belirtke tablosu oluşturulmuş, belirtke tablosuna göre beceri sınavinın madde havuzu hazırlanmış, hazırlanan madde havuzu kapsam geçerliliği için uzman görüşlerine sunulmuş, beş farklı alan uzmanından havuzdaki dört maddenin her biri için 1 (en yüksek) ila 4 (en düşük) arasında sıralı puanlama yapması istenmiş, uzman görüşlerine göre en yüksek toplam puanı alan maddenin ön-son test beceri sinavı olarak kullanılmasına karar verilmiştir.

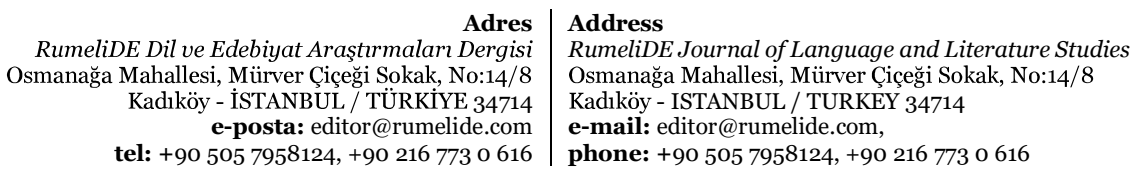


Öğrenci yapısı podcast (ses yayını) oluşturma süreçlerinin yabancı dil olarak Türkçe öğrenenlerin konuşma ve yazma becerisi ile bu becerilerdeki öz yeterliliklerine etkisi / O. K. Yorgancı \& B. Baş (256-282. s.)

Tablo 4: Orta (B1-Bağımsız) düzey yazma Türkçe yeterlilik sınavı uzman görüşleri

\begin{tabular}{lllllll}
\hline & P1 & P2 & P3 & P4 & P5 & $\begin{array}{l}\text { Toplam } \\
\text { Puan }\end{array}$ \\
\hline M1 & 4 & 4 & 4 & 4 & 3 & 19 \\
M2 & 3 & 3 & 3 & 3 & 4 & 16 \\
M3 & 2 & 2 & 2 & 2 & 2 & 10 \\
M4 & 1 & 1 & 1 & 1 & 1 & 5 \\
\hline
\end{tabular}

Uzman görüşlerine göre en yüksek puanı alan M1 ön-son test yazma becerisi sinav sorusu olarak kullanılmıştır.

Araştırmada geliştirilen bağımsız konuşma becerisi ölçme aracından elde edilecek verilerin değerlendirilebilmesi için yine araştırmacı tarafından bir bağımsız konuşma becerisi dereceli puanlama anahtarı geliştirilmiştir.

DPA’nın kapsam geçerliliği için alınan uzman görüşleri aşağıda gösterilmiştir.

Tablo 5: Yabancı Dil Olarak Türkçe öğrenenler için B1 düzeyi bağımsız konuşma becerisi dereceli puanlama anahtarına yönelik uzman görüşleri

\begin{tabular}{|c|c|c|c|c|c|c|c|c|c|c|c|c|c|c|c|c|c|c|}
\hline & \multicolumn{3}{|c|}{ 1.uzman } & \multicolumn{3}{|c|}{ 2.uzman } & \multicolumn{3}{|c|}{ 3.uzman } & \multicolumn{3}{|c|}{ 4.uzman } & \multicolumn{3}{|c|}{ 5.uzman } & \multicolumn{3}{|c|}{ Toplam } \\
\hline & 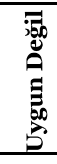 & 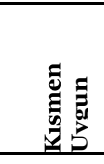 & 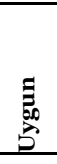 & 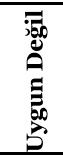 & 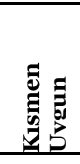 & 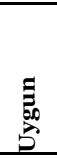 & 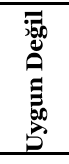 & 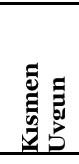 & 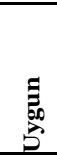 & 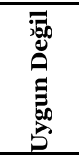 & 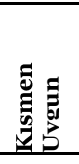 & 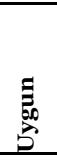 & 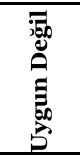 & 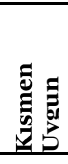 & 豆 & 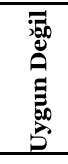 & 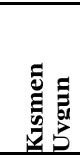 & 总 \\
\hline $\begin{array}{l}1 . \\
\text { Madde }\end{array}$ & & & + & & + & & & & + & & & + & & & + & & 1 & 4 \\
\hline $\begin{array}{l}2 . \\
\text { Madde }\end{array}$ & & & + & & & + & & & + & & & + & & & + & & & 5 \\
\hline $\begin{array}{l}3 . \\
\text { Madde }\end{array}$ & & & + & & & + & & & + & & & + & & & + & & & 5 \\
\hline $\begin{array}{l}4 . \\
\text { Madde }\end{array}$ & & & + & & & + & & & + & & & + & & & + & & & 5 \\
\hline $\begin{array}{l}5 . \\
\text { Madde }\end{array}$ & & & + & & & + & & + & & & & + & & & + & & 1 & 4 \\
\hline $\begin{array}{l}6 . \\
\text { Madde }\end{array}$ & & & + & & & + & & & + & & & + & & & + & & & 5 \\
\hline $\begin{array}{l}7 . \\
\text { Madde }\end{array}$ & & & + & & & + & & & + & & & + & & & + & & & 5 \\
\hline $\begin{array}{l}8 . \\
\text { Madde }\end{array}$ & & & + & & & + & & & + & & & + & & & + & & & 5 \\
\hline $\begin{array}{l}9 . \\
\text { Madde }\end{array}$ & & & + & & & + & & & + & & & + & & & + & & & 5 \\
\hline $\begin{array}{l}10 . \\
\text { Madde }\end{array}$ & & & + & & & + & & & + & & & + & & & + & & & 5 \\
\hline $\begin{array}{l}\text { 11. } \\
\text { Madde }\end{array}$ & & & + & & & + & & & + & & & + & & & + & & & 5 \\
\hline $\begin{array}{l}12 . \\
\text { Madde }\end{array}$ & & & + & & & + & & & + & & & + & & & + & & & 5 \\
\hline & & $\begin{array}{c}\text { RumeliL } \\
\text { Osmanağa } \\
\text { a }\end{array}$ & $\begin{array}{l}D E D i \\
\text { Mah } \\
\text { Kad } \\
\text { tel: }+\end{array}$ & $\begin{array}{l}v e E d \\
\text { lesi, } \\
\text { köy - I } \\
\text { e-p } \\
90505\end{array}$ & $\begin{array}{l}\text { iiyat Ar } \\
\text { irver Cii } \\
\text { TANBUI } \\
\text { sta: ed } \\
7958124\end{array}$ & 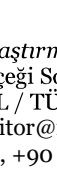 & $\begin{array}{l}\text { A } \\
\text { alarn } D \\
\text { kak, } \mathrm{NC} \\
\text { RKIYE } \\
\text { umelid }\end{array}$ & $\begin{array}{l}\text { dres } \\
\text { argisi } \\
: 14 / 8 \\
44714 \\
. c 00 \\
0616\end{array}$ & $\begin{array}{l}\text { Add } \\
\text { Rum } \\
\text { Osm } \\
\text { Kad } \\
\text { e-m } \\
\text { pho }\end{array}$ & $\begin{array}{l}\text { ress } \\
\text { eliDE Jo } \\
\text { anağa } \\
\text { zöy - IST } \\
\text { iil: edit } \\
\text { ee: +9o }\end{array}$ & $\begin{array}{l}\text { Irnal of } \\
\text { hallesi, } \\
\text { ANBUL } \\
\text { r@rume } \\
\text { so5 795 }\end{array}$ & $\begin{array}{l}\text { Lang } \\
\text { Mürv } \\
\text { / TU } \\
\text { elide.c } \\
\text { 8124, }\end{array}$ & $\begin{array}{l}\text { uage an } \\
\text { er Ciçĕ } \\
\text { RKEY } \\
\text { om, } \\
\text { +9O } 216\end{array}$ & $\begin{array}{l}\text { Litera } \\
\text { Sokak, } \\
714 \\
773 \text { o } 6\end{array}$ & $\begin{array}{l}\text { ature } \\
\text { No:1 } \\
616\end{array}$ & $\begin{array}{l}\text { tudies } \\
/ 8\end{array}$ & & \\
\hline
\end{tabular}


The impact of student - generated podcast formation processes on speaking and writing skills of learners of Turkish as a foreign language and their self-efficacy in these skills / O. K. Yorgancı \& B. Baş (pp. 256-282)

13 .

Madde

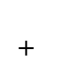

14.

Madde

$+$

15 .

Madde

$+$

16.

Madde

17.

Madde

18.

Madde

19.

Madde

20.

Madde

21.

Madde

22.

Madde

23.

Madde

+
+
+
+
+
+
+
+
+

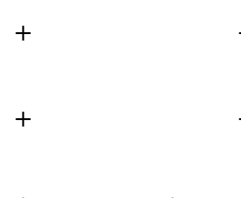

$+$

$+$

5

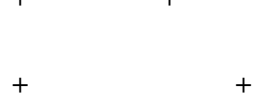

$+$

5

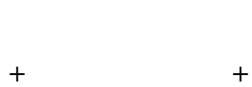

5

$+$

$+$

5

$+$

5

$+\quad+$

5

$+\quad+$

5

$+\quad+$

5

Uzman görüşlerinin yüksek düzeyde örtüşmesi, ilgili DPA’nın kapsam geçerliliğine sahip olduğunu göstermiştir.

DPA'nın güvenilirliği için 3 farklı alan uzmanının 30 farklı öğrencinin bağımsız konuşma becerisi sınavını puanlandığı verilere ait güvenilirlik bulguları aşağıda gösterilmiştir.

Tablo 6: Yabancı Dil Olarak Türkçe öğrenenler için B1 düzeyi bağımsız konuşma becerisi dereceli puanlama anahtarına yönelik güvenirlik bulguları

\begin{tabular}{|c|c|c|c|c|c|}
\hline \multirow{2}{*}{ Madde } & & \multirow{2}{*}{\multicolumn{2}{|c|}{$\begin{array}{l}\text { Puanlayicilar Arasi Korelasyon (Intraclass } \\
\text { Correlation) }\end{array}$}} & \multicolumn{2}{|c|}{$\begin{array}{l}\text { \% } 95 \text { Güven } \\
\text { Aralığı }\end{array}$} \\
\hline & & & & $\begin{array}{l}\text { Alt } \\
\text { Sinir }\end{array}$ & $\begin{array}{l}\text { Üst } \\
\text { Sinir }\end{array}$ \\
\hline \multirow[b]{2}{*}{ 1. Madde } & Tek Ölçümler & .612 & & .415 & .774 \\
\hline & $\begin{array}{l}\text { Ortalama } \\
\text { Ölçümler }\end{array}$ & .826 & & .680 & .911 \\
\hline \multirow[b]{2}{*}{ 2. Madde } & Tek Ölçümler & 691 & & .517 & .825 \\
\hline & $\begin{array}{l}\text { Ortalama } \\
\text { Ölçümler }\end{array}$ & .870 & & .762 & .934 \\
\hline \multirow[b]{2}{*}{ 3. Madde } & Tek Ölçümler & .739 & & .582 & .855 \\
\hline & $\begin{array}{l}\text { Ortalama } \\
\text { Ölçümler }\end{array}$ & .895 & & .807 & .946 \\
\hline \multirow[b]{2}{*}{ 4. Madde } & Tek Ölçümler & .673 & & .493 & .814 \\
\hline & $\begin{array}{l}\text { Ortalama } \\
\text { Ölçümler }\end{array}$ & .861 & & .745 & .929 \\
\hline \multirow[t]{2}{*}{ 5. Madde } & Tek Ölçümler & .714 & & .548 & .840 \\
\hline & $\begin{array}{r}\text { RumeliDE Dil } \\
\text { Osmanağa Mahal } \\
\text { Kadık } \\
\text { tel: }+9\end{array}$ & \begin{tabular}{r|} 
Adres \\
ebiyat Araşttrmalarn Dergisi \\
Iürver Çiçği Sokak, No:14/8 \\
STANBUL / TÜRKIYYE 34714 \\
osta: editor@rumelide.com \\
7958124, +90 216 773 0 616
\end{tabular} & $\begin{array}{l}\text { Address } \\
\text { RumeliDE Journal of Language c } \\
\text { Osmanağa Mahallesi, Mürver Çç̧ } \\
\text { Kadıköy - ISTANBUL / TURKEY } \\
\text { e-mail: editor@rumelide.com, } \\
\text { phone: +90 505 7958124, +90 } 2\end{array}$ & $\begin{array}{l}\text { rature Stu } \\
\text { k, No:14/8 } \\
616\end{array}$ & \\
\hline
\end{tabular}


Öğrenci yapısı podcast (ses yayını) oluşturma süreçlerinin yabancı dil olarak Türkçe öğrenenlerin konuşma ve yazma becerisi ile bu becerilerdeki öz yeterliliklerine etkisi / O. K. Yorgancı \& B. Baş (256-282. s.)

\begin{tabular}{|c|c|c|c|c|}
\hline & $\begin{array}{l}\text { Ortalama } \\
\text { Ölçümler }\end{array}$ & .882 & .785 & .940 \\
\hline \multirow[b]{2}{*}{ 6. Madde } & Tek Ölçümler & .737 & .579 & .853 \\
\hline & $\begin{array}{l}\text { Ortalama } \\
\text { Ölçümler }\end{array}$ & .894 & .805 & .946 \\
\hline \multirow[b]{2}{*}{ 7. Madde } & Tek Ölçümler & .508 & .291 & .701 \\
\hline & $\begin{array}{l}\text { Ortalama } \\
\text { Ölçümler }\end{array}$ & .756 & .552 & .876 \\
\hline \multirow[b]{2}{*}{ 8. Madde } & Tek Ölçümler & .622 & .427 & .780 \\
\hline & $\begin{array}{l}\text { Ortalama } \\
\text { Ölçümler }\end{array}$ & .831 & .691 & .914 \\
\hline \multirow[b]{2}{*}{ 9. Madde } & Tek Ölçümler & .687 & .511 & .822 \\
\hline & $\begin{array}{l}\text { Ortalama } \\
\text { Ölçümler }\end{array}$ & .868 & .758 & .933 \\
\hline \multirow{2}{*}{$\begin{array}{l}10 . \\
\text { Madde }\end{array}$} & Tek Ölçümler & .666 & .484 & .809 \\
\hline & $\begin{array}{l}\text { Ortalama } \\
\text { Ölçümler }\end{array}$ & .857 & .737 & .927 \\
\hline \multirow[b]{2}{*}{ 11. Madde } & Tek Ölçümler & .624 & .429 & .782 \\
\hline & $\begin{array}{l}\text { Ortalama } \\
\text { Ölçümler }\end{array}$ & .833 & 693 & .915 \\
\hline \multirow{2}{*}{$\begin{array}{l}12 . \\
\text { Madde }\end{array}$} & Tek Ölçümler & .458 & .236 & .664 \\
\hline & $\begin{array}{l}\text { Ortalama } \\
\text { Ölçümler }\end{array}$ & .717 & .481 & .856 \\
\hline \multirow{2}{*}{$\begin{array}{l}13 . \\
\text { Madde }\end{array}$} & Tek Ölçümler & .694 & .520 & .827 \\
\hline & $\begin{array}{l}\text { Ortalama } \\
\text { Ölçümler }\end{array}$ & .872 & .765 & .935 \\
\hline \multirow{2}{*}{$\begin{array}{l}14 . \\
\text { Madde }\end{array}$} & Tek Ölçümler & .549 & .339 & .730 \\
\hline & $\begin{array}{l}\text { Ortalama } \\
\text { Ölçümler }\end{array}$ & .785 & .606 & .890 \\
\hline \multirow{2}{*}{$\begin{array}{l}15 . \\
\text { Madde }\end{array}$} & Tek Ölçümler & .623 & .429 & .781 \\
\hline & $\begin{array}{l}\text { Ortalama } \\
\text { Ölçümler }\end{array}$ & .832 & .693 & .915 \\
\hline \multirow{2}{*}{$\begin{array}{l}16 . \\
\text { Madde }\end{array}$} & Tek Ölçümler & .792 & .658 & .886 \\
\hline & $\begin{array}{l}\text { Ortalama } \\
\text { Ölçümler }\end{array}$ & .920 & .852 & .959 \\
\hline \multirow{2}{*}{$\begin{array}{l}17 . \\
\text { Madde }\end{array}$} & Tek Ölçümler & .635 & .444 & .789 \\
\hline & $\begin{array}{l}\text { Ortalama } \\
\text { Ölçümler }\end{array}$ & .839 & .706 & .918 \\
\hline \multirow{2}{*}{$\begin{array}{l}18 . \\
\text { Madde }\end{array}$} & Tek Ölçümler & .713 & .546 & .839 \\
\hline & $\begin{array}{l}\text { Ortalama } \\
\text { Ölçümler }\end{array}$ & .882 & .783 & .940 \\
\hline \multirow{4}{*}{$\begin{array}{l}19 . \\
\text { Madde }\end{array}$} & Tek Ölçümler & .494 & .276 & .691 \\
\hline & $\begin{array}{l}\text { Ortalama } \\
\text { Ölçümler }\end{array}$ & .746 & .534 & .870 \\
\hline & Tek Ölçümler & .561 & .353 & .739 \\
\hline & $\begin{array}{r}\text { RumeliDE Dil } \\
\text { Osmanağa Mahal } \\
\text { Kadık } \\
\text { tel: }+9\end{array}$ & $\begin{array}{r}\text { Adres } \\
\text { ebiyat Arasstrmaları Dergisi } \\
\text { Iürver Ciçeği Sokak, No:14/8 } \\
\text { STANBUL / TÜRKİYE 34714 } \\
\text { osta: editor@rumelide.com } \\
7958124,+902167730616\end{array}$ & $\begin{array}{l}\text { Address } \\
\text { RumeliDE Journal of Language and Literature Studies } \\
\text { Osmanağa Mahallesi, Mürver Ciccĕi Sokak, No:14/8 } \\
\text { Kadıköy - ISTANBUL / TURKEY } 34714 \\
\text { e-mail: editor@rumelide.com, } \\
\text { phone: +90 505 7958124, +90 } 216773 \text { o } 616\end{array}$ & \\
\hline
\end{tabular}


The impact of student - generated podcast formation processes on speaking and writing skills of learners of Turkish as a foreign language and their self-efficacy in these skills / O. K. Yorgancı \& B. Baş (pp. 256-282)

\begin{tabular}{|c|c|c|c|c|}
\hline $\begin{array}{l}20 . \\
\text { Madde }\end{array}$ & $\begin{array}{l}\text { Ortalama } \\
\text { Ölçümler }\end{array}$ & .793 & .621 & .895 \\
\hline \multirow{2}{*}{$\begin{array}{l}21 . \\
\text { Madde }\end{array}$} & Tek Ölçümler & .660 & .476 & .805 \\
\hline & $\begin{array}{l}\text { Ortalama } \\
\text { Ölçümler }\end{array}$ & .853 & .731 & .925 \\
\hline \multirow{2}{*}{$\begin{array}{l}22 . \\
\text { Madde }\end{array}$} & Tek Ölçümler & .709 & .541 & .836 \\
\hline & $\begin{array}{l}\text { Ortalama } \\
\text { Ölçümler }\end{array}$ & .880 & .779 & .939 \\
\hline \multirow{2}{*}{$\begin{array}{l}23 . \\
\text { Madde }\end{array}$} & Tek Ölçümler & .762 & .614 & .868 \\
\hline & $\begin{array}{l}\text { Ortalama } \\
\text { Ölçümler }\end{array}$ & .906 & .827 & .952 \\
\hline \multirow[b]{2}{*}{ Toplam } & Tek Ölçümler & .963 & .933 & .981 \\
\hline & $\begin{array}{l}\text { Ortalama } \\
\text { Ölçümler }\end{array}$ & .987 & .977 & .993 \\
\hline
\end{tabular}

3 farklı alan uzmanı tarafından ayrı ayrı değerlendirilen 30 katılımcının sınavlarından elde edilen verilere göre hesaplanan değerlendiriciler arası tutarlılık katsayısının o,987 olması ilgili DPA'nın güvenilir olduğunu göstermiştir.

Araştırmada geliştirilen karşılıklı konuşma becerisi ölçme aracından elde edilecek verilerin değerlendirilebilmesi için yine araştırmacı tarafından bir karşılık konuşma becerisi dereceli puanlama anahtarı geliştirilmiştir.

DPA'nın kapsam geçerliliği için alınan uzman görüşleri aşă̆ıda gösterilmiştir.

Tablo 7: Yabancı Dil Olarak Türkçe öğrenenler için B1 düzeyi karşılıklı konuşma becerisi dereceli puanlama anahtarına yönelik uzman görüşleri

\begin{tabular}{|c|c|c|c|c|c|c|c|c|c|c|c|c|c|c|c|c|c|c|}
\hline & \multicolumn{3}{|c|}{ 1.uzman } & \multicolumn{3}{|c|}{ 2.uzman } & \multicolumn{3}{|c|}{ 3.uzman } & \multicolumn{3}{|c|}{ 4.uzman } & \multicolumn{3}{|c|}{ 5.uzman } & \multicolumn{3}{|c|}{ Toplam } \\
\hline & 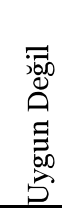 & 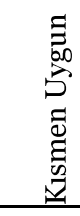 & $\begin{array}{l}\Xi \\
\Xi \\
0 \\
\sigma \\
\end{array}$ & 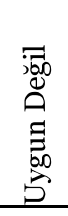 & 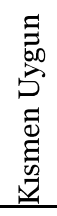 & $\begin{array}{l}\Xi \\
0 \\
\sigma \\
\sigma \\
\sigma\end{array}$ & $\begin{array}{l}\overline{j 00} \\
0 \\
0 \\
\Xi \\
0 \\
0 \\
0 \\
0\end{array}$ & 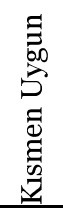 & $\begin{array}{l}\Xi \\
5 \\
\vdots \\
\sigma \\
\end{array}$ & 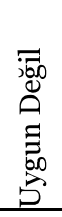 & 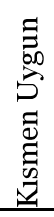 & $\begin{array}{l}\Xi \\
\vdots \\
\sigma \\
\sigma \\
\end{array}$ & 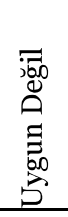 & 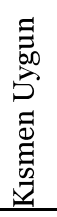 & 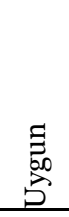 & 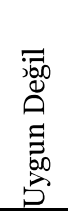 & 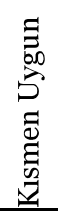 & $\begin{array}{l}\Xi \\
\vdots \\
5 \\
\vdots \\
\end{array}$ \\
\hline $\begin{array}{l}\text { 1. } \\
\text { Madd } \\
\text { e }\end{array}$ & & & + & & & + & & & + & & & + & & & + & & & 5 \\
\hline $\begin{array}{l}2 . \\
\text { Madd } \\
\text { e }\end{array}$ & & & + & & & + & & & + & & & + & & & + & & & 5 \\
\hline $\begin{array}{l}3 . \\
\text { Madd } \\
\text { e }\end{array}$ & & & + & & & + & & & + & & & + & & & + & & & 5 \\
\hline $\begin{array}{l}4 . \\
\text { Madd } \\
\text { e }\end{array}$ & & & + & & & + & & & + & & & + & & & + & & & 5 \\
\hline $\begin{array}{l}5 . \\
\text { Madd } \\
\text { e }\end{array}$ & & & + & & & + & & & + & & & + & & & + & & & 5 \\
\hline & & $\begin{array}{r}\text { Rum } \\
\text { Osman }\end{array}$ & $\begin{array}{r}l i D E D \\
\text { liDE Mah } \\
\text { Kad } \\
\text { tel: }\end{array}$ & $\begin{array}{l}\text { lve Ed } \\
\text { llesi, } \\
\text { köy - I } \\
\text { e-I } \\
90505\end{array}$ & $\begin{array}{l}\text { biyat } \\
\text { ürver } \\
\text { TANB } \\
\text { osta: } \\
79581\end{array}$ & $\begin{array}{l}\text { raşturn } \\
\text { içeği S } \\
\text { JL / Tü } \\
\text { ditor@ } \\
4,+90\end{array}$ & $\begin{array}{l}\text { zaları } \\
\text { kak, N } \\
\text { RKIYY } \\
\text { rumeli } \\
216773\end{array}$ & $\begin{array}{l}\text { Idres } \\
\text { ergisi } \\
: 14 / 8 \\
34714 \\
\text { e.com } \\
\text { o } 616\end{array}$ & $\begin{array}{l}\text { Add } \\
\text { Rum } \\
\text { Osm } \\
\text { Kad1 } \\
\text { e-m } \\
\text { phor }\end{array}$ & $\begin{array}{l}\text { ess } \\
\text { liDE } J \\
\text { nağa } \\
\text { :öy - IS } \\
\text { il: edit } \\
\text { le: }+90\end{array}$ & $\begin{array}{l}\text { rnal } \\
\text { halle } \\
\text { NBI }\end{array}$ & $\begin{array}{l}\text { flang } \\
\text { Lür } \\
\text { L / TU } \\
\text { nelide. } \\
58124,\end{array}$ & $\begin{array}{l}\text { lage an } \\
\text { r Çiçe } \\
\mathrm{KEY} \\
\mathrm{Om} \\
+90 \\
+90\end{array}$ & $\begin{array}{l}\text { Liter } \\
\text { Sokak } \\
714 \\
7730\end{array}$ & $\begin{array}{l}\text { ature } S \\
\text {, No:14 } \\
616\end{array}$ & $\begin{array}{l}\text { udies } \\
88\end{array}$ & & \\
\hline
\end{tabular}


Öğrenci yapısı podcast (ses yayını) oluşturma süreçlerinin yabancı dil olarak Türkçe öğrenenlerin konuşma ve yazma becerisi ile bu becerilerdeki öz yeterliliklerine etkisi / O. K. Yorgancı \& B. Baş (256-282. s.)

6.

Madd

e

7.

Madd

$\mathrm{e}$

8.

Madd

e

9.

Madd

e

10.

Madd

e

11.

Madd

e

12.

Madd

e

13.

Madd

e

14.

Madd

e

15.

Madd

e

16.

Madd

e

17.

Madd

e

18.

Madd

e

19

Madd

e

20.

Madd

e

21

Madd

e

22.

Madd

e

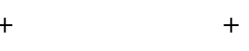

$+$

$+$

$+$

$+$

$+$

$+$

$+$

$+$

$+$

$+$
5

5

5

5

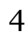

5

5

4

5

5

5

5
RumeliDE Dil ve Edebiyat Araştırmalar Dergis Osmanağa Mahallesi, Mürver Ciceği Sokak, No:14/8

Kadıköy - ISTANBUL / TÜRKIYE 34714 e-posta: editor@rumelide.com

tel: +90 505 7958124, +90 2167730616
Address

RumeliDE Journal of Language and Literature Studies Osmanağa Mahallesi, Mürver Çiçeği Sokak, No:14/8

Kadıköy - ISTANBUL / TURKEY 34714

e-mail: editor@rumelide.com,

phone: +90 5057958124, +90 2167730616 
The impact of student - generated podcast formation processes on speaking and writing skills of learners of Turkish as a foreign language and their self-efficacy in these skills / O. K. Yorgancı \& B. Baş (pp. 256-282)

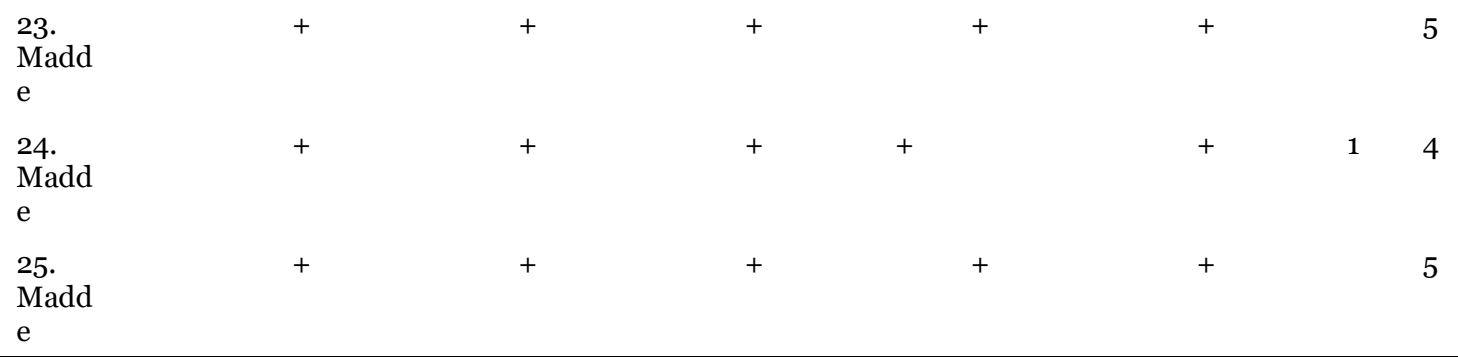

Uzman görüşlerinin yüksek düzeyde örtüşmesi, ilgili DPA’nın kapsam geçerliliğine sahip olduğunu göstermiştir.

DPA'nın güvenilirliği için 3 farklı alan uzmanının 30 farklı öğrencinin karşlıklı konuşma becerisi sınavını puanlandığı verilere ait güvenilirlik bulguları aşağıda gösterilmiştir.

Tablo 8: Yabancı Dil Olarak Türkçe öğrenenler için Bı düzeyi karşılıklı konuşma becerisi dereceli puanlama anahtarı'na yönelik güvenirlik bulguları

\begin{tabular}{|c|c|c|c|c|}
\hline \multirow{2}{*}{ Madde } & & \multirow{2}{*}{$\begin{array}{l}\text { Puanlayıcılar Arası } \\
\text { Korelasyon } \\
\text { (Intraclass } \\
\text { Correlation) }\end{array}$} & \multicolumn{2}{|c|}{ \% 95 Güven Aralığı } \\
\hline & & & Alt Sinir & Üst Sinır \\
\hline \multirow{2}{*}{ 1. Madde } & Tek Ölçümler & .708 & .539 & .835 \\
\hline & Ortalama Ölçümler & .879 & .778 & .938 \\
\hline \multirow{2}{*}{ 2. Madde } & Tek Ölçümler & .583 & .380 & .754 \\
\hline & Ortalama Ölçümler & .808 & .648 & .902 \\
\hline \multirow{2}{*}{ 3. Madde } & Tek Ölçümler & .828 & .713 & .907 \\
\hline & Ortalama Ölçümler & .935 & .882 & .967 \\
\hline \multirow{2}{*}{ 4. Madde } & Tek Ölçümler & .682 & .505 & .819 \\
\hline & Ortalama Ölçümler & .865 & .753 & .932 \\
\hline \multirow{2}{*}{ 5. Madde } & Tek Ölçümler & .782 & .644 & .881 \\
\hline & Ortalama Ölçümler & .915 & .845 & .957 \\
\hline \multirow{2}{*}{ 6. Madde } & Tek Ölçümler & .796 & .664 & .889 \\
\hline & Ortalama Ölçümler & .921 & .855 & .960 \\
\hline \multirow{2}{*}{ 7. Madde } & Tek Ölçümler & .703 & .533 & .833 \\
\hline & Ortalama Ölçümler & .877 & .774 & .937 \\
\hline \multirow{2}{*}{ 8. Madde } & Tek Ölçümler & .745 & .591 & .858 \\
\hline & Ortalama Ölçümler & .898 & .812 & .948 \\
\hline \multirow{2}{*}{ 9. Madde } & Tek Ölçümler & .683 & .506 & .820 \\
\hline & Ortalama Ölçümler & .866 & .754 & .932 \\
\hline \multirow{2}{*}{ 10. Madde } & Tek Ölçümler & .731 & .571 & .850 \\
\hline & Ortalama Ölçümler & .891 & .800 & .944 \\
\hline \multirow{2}{*}{ 11. Madde } & Tek Ölçümler & .833 & .719 & .910 \\
\hline & Ortalama Ölçümler & .937 & .885 & .968 \\
\hline & $\begin{array}{r}\text { Adres } \\
\text { RumeliDE Dil ve Edebiyat Arasstrmalarm Dergis } \\
\text { Osmanağa Mahallesi, Mürver Ciçeği Sokak, No:14/8 } \\
\text { Kadiköy - İSTANBUL / TÜRKIYYE } 3471 \\
\text { e-posta: editor@rumelide.con } \\
\text { tel: }+90 \text { 505 7958124, +90 } 216773 \text { o } 616\end{array}$ & \begin{tabular}{l|l} 
ss & Address \\
si & RumeliDE Journal of Lan \\
8 & Osmanağa Mahallesi, Mü \\
$\mathrm{in}$ & Kadiköy - ISTANBUL / T1 \\
$\mathrm{m}$ & e-mail: editor@rumelide \\
16 & phone: +90 505 795812
\end{tabular} & $\begin{array}{l}\text { age and Litera } \\
\text { r Çiçeği Sokak, } \\
\text { KEY } 34714 \\
\text { m, } \\
90216773 \text { o } 6\end{array}$ & \\
\hline
\end{tabular}




\begin{tabular}{|c|c|c|c|c|}
\hline \multirow{2}{*}{ 12. Madde } & Tek Ölçümler & .753 & .602 & .863 \\
\hline & Ortalama Ölçümler & .902 & .820 & .950 \\
\hline \multirow{2}{*}{ 13. Madde } & Tek Ölçümler & .756 & .607 & .865 \\
\hline & Ortalama Ölçümler & .903 & .822 & .951 \\
\hline \multirow{2}{*}{ 14. Madde } & Tek Ölçümler & .784 & .646 & .881 \\
\hline & Ortalama Ölçümler & .916 & .845 & .957 \\
\hline \multirow{2}{*}{ 15. Madde } & Tek Ölçümler & .699 & .528 & .830 \\
\hline & Ortalama Ölçümler & .875 & .770 & .936 \\
\hline \multirow{2}{*}{ 16. Madde } & Tek Ölçümler & .762 & .614 & .868 \\
\hline & Ortalama Ölçümler & .906 & .827 & .952 \\
\hline \multirow{2}{*}{ 17. Madde } & Tek Ölçümler & .813 & .689 & .898 \\
\hline & Ortalama Ölçümler & .929 & .869 & .964 \\
\hline \multirow{2}{*}{ 18. Madde } & Tek Ölçümler & .747 & .593 & .860 \\
\hline & Ortalama Ölçümler & .899 & .814 & .948 \\
\hline \multirow{2}{*}{ 19. Madde } & Tek Ölçümler & .594 & .392 & .761 \\
\hline & Ortalama Ölçümler & .814 & .659 & .905 \\
\hline \multirow{2}{*}{ 20. Madde } & Tek Ölçümler & .823 & .704 & .904 \\
\hline & Ortalama Ölçümler & .933 & .877 & .966 \\
\hline \multirow{2}{*}{ 21. Madde } & Tek Ölçümler & .802 & .673 & .892 \\
\hline & Ortalama Ölçümler & .924 & .860 & .961 \\
\hline \multirow{2}{*}{ 22. Madde } & Tek Ölçümler & .844 & .736 & .916 \\
\hline & Ortalama Ölçümler & .942 & .893 & .970 \\
\hline \multirow{2}{*}{ 23. Madde } & Tek Ölçümler & .827 & .711 & .907 \\
\hline & Ortalama Ölçümler & .935 & .881 & .967 \\
\hline \multirow{2}{*}{ 24. Madde } & Tek Ölçümler & .810 & .686 & .897 \\
\hline & Ortalama Ölçümler & .928 & .867 & .963 \\
\hline \multirow{2}{*}{ 25. Madde } & Tek Ölçümler & .770 & .626 & .873 \\
\hline & Ortalama Ölçümler & .909 & .834 & .954 \\
\hline \multirow{2}{*}{ Toplam } & Tek Ölçümler & .948 & .907 & .973 \\
\hline & Ortalama Ölçümler & .982 & .967 & .991 \\
\hline
\end{tabular}

3 farklı alan uzmanı tarafından ayrı ayrı değerlendirilen 30 katılımcının sınavlarından elde edilen verilere göre hesaplanan değerlendiriciler arası tutarlılı katsayısının 0,982 olması ilgili DPA'nın güvenilir olduğunu göstermiştir.

Araştırmada geliştirilen yazma becerisi ölçme aracından elde edilecek verilerin değerlendirilebilmesi için yine araştırmacı tarafından bir yazma becerisi dereceli puanlama anahtarı geliştirilmiştir.

DPA'nın kapsam geçerliliği için alınan uzman görüşleri aşağıda gösterilmiştir.

Tablo 9: Yabancı Dil Olarak Türkçe öğrenenler için B1 düzeyi yazma becerisi dereceli puanlama anahtarına yönelik uzman görüşleri

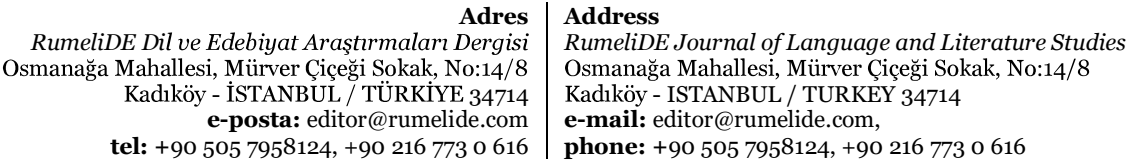


The impact of student - generated podcast formation processes on speaking and writing skills of learners of Turkish as a foreign language and their self-efficacy in these skills / O. K. Yorgancı \& B. Baş (pp. 256-282)

\begin{tabular}{|c|c|c|c|c|c|c|c|c|c|c|c|c|c|c|c|c|c|c|}
\hline & \multicolumn{2}{|c|}{ 1.uzman } & \multicolumn{3}{|c|}{ 2.uzman } & \multicolumn{3}{|c|}{ 3.uzman } & \multicolumn{3}{|c|}{ 4.uzman } & \multicolumn{3}{|c|}{ 5.uzman } & \multicolumn{4}{|c|}{ Toplam } \\
\hline & 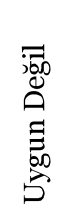 & 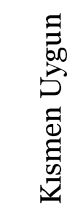 & 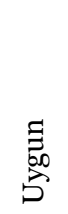 & 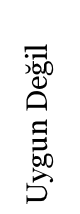 & 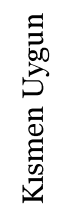 & 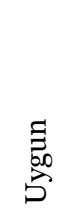 & 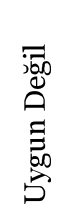 & 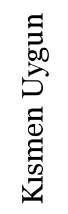 & $\begin{array}{l}\Xi \\
\vdots \\
\stackrel{5}{\sigma}\end{array}$ & 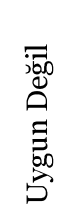 & 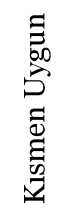 & $\begin{array}{l}\Xi \\
\vdots \\
\sigma \\
\sigma\end{array}$ & $\begin{array}{l}\overline{300} \\
0 \\
\square \\
\Xi \\
50 \\
5 \\
\sigma\end{array}$ & 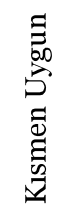 & 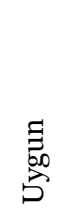 & 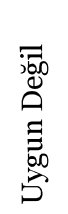 & 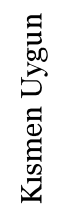 & $\begin{array}{l}\Xi \\
\stackrel{5}{5} \\
\stackrel{5}{\sigma}\end{array}$ \\
\hline $\begin{array}{l}1 . \\
\text { Madd } \\
\text { e }\end{array}$ & & & + & & & + & & & + & & & + & & & + & & & 5 \\
\hline $\begin{array}{l}2 . \\
\text { Madd } \\
\text { e }\end{array}$ & & & + & & & + & & & + & & & + & & & + & & & 5 \\
\hline $\begin{array}{l}3 . \\
\text { Madd } \\
\text { e }\end{array}$ & & & + & & & + & & & + & & & + & & & + & & & 5 \\
\hline $\begin{array}{l}4 . \\
\text { Madd } \\
\text { e }\end{array}$ & & + & & & & + & & & + & & & + & & & + & & 1 & 4 \\
\hline $\begin{array}{l}5 . \\
\text { Madd } \\
\text { e }\end{array}$ & & & + & & & + & & & + & & & + & & & + & & & 5 \\
\hline $\begin{array}{l}6 . \\
\text { Madd } \\
\text { e }\end{array}$ & & & + & & & + & & & + & & & + & & & + & & & 5 \\
\hline $\begin{array}{l}7 . \\
\text { Madd } \\
\text { e }\end{array}$ & & & + & & & + & & & + & & + & & & & + & & 1 & 4 \\
\hline $\begin{array}{l}8 . \\
\text { Madd } \\
\text { e }\end{array}$ & & & + & & & + & & & + & & & + & & & + & & & 5 \\
\hline $\begin{array}{l}9 . \\
\text { Madd } \\
\text { e }\end{array}$ & & & + & & & + & & & + & & & + & & & + & & & 5 \\
\hline $\begin{array}{l}10 . \\
\text { Madd } \\
\text { e }\end{array}$ & & & + & & + & & & & + & & & + & & & + & & 1 & 4 \\
\hline $\begin{array}{l}11 . \\
\text { Madd } \\
\text { e }\end{array}$ & & & + & & & + & & & + & & & + & & & + & & & 5 \\
\hline $\begin{array}{l}12 . \\
\text { Madd } \\
\text { e }\end{array}$ & & & + & & & + & & & + & & & + & & & + & & & 5 \\
\hline $\begin{array}{l}13 . \\
\text { Madd } \\
\text { e }\end{array}$ & & & + & & & + & & & + & & & + & & & + & & & 5 \\
\hline $\begin{array}{l}14 . \\
\text { Madd } \\
\text { e }\end{array}$ & & & + & & & + & & & + & & & + & & & + & & & 5 \\
\hline $\begin{array}{l}15 . \\
\text { Madd } \\
\text { e }\end{array}$ & & & + & & & + & & & + & & & + & & + & & & 1 & 4 \\
\hline & & $\begin{array}{r}\text { Rum } \\
\text { Osmana }\end{array}$ & $\begin{array}{l}\text { LiDE } \\
\text { Ka Mah } \\
\text { Kad } \\
\text { tel: }\end{array}$ & $\begin{array}{l}\text { lve Ede } \\
\text { allesi, M } \\
\text { kö̀y - Is } \\
\text { e-p } \\
90505\end{array}$ & $\begin{array}{l}\text { biyat } \\
\text { ürver } \\
\text { TANI } \\
\text { osta: } \\
7958\end{array}$ & $\begin{array}{l}\text { raştur } \\
\text { riçeği S } \\
\text { JL / Ti } \\
\text { ditor@ } \\
4,+90\end{array}$ & $\begin{array}{l} \\
\text { ralart } \\
\text { kak, } \\
\text { RKIYY } \\
\text { Rumelid } \\
216773\end{array}$ & $\begin{array}{l}\text { dres } \\
\text { ergisi } \\
: 14 / 8 \\
34714 \\
\text { e.com } \\
\text { o } 616\end{array}$ & $\begin{array}{l}\text { Add } \\
\text { Rum } \\
\text { Osm } \\
\text { Kad1 } \\
\text { e-ma } \\
\text { phor }\end{array}$ & $\begin{array}{l}\text { ress } \\
\text { eliDE J } \\
\text { anağa } \\
\text { köy - IS } \\
\text { ill: edit } \\
\text { ee: +90 }\end{array}$ & $\begin{array}{l}\text { urnal } \\
\text { ahalle } \\
\text { CaNBL } \\
\text { or@ @ ru } \\
5057\end{array}$ & $\begin{array}{l}\text { f Lang } \\
\text { i. Mürv } \\
\text { L / TU1 } \\
\text { nelide.c } \\
58124,\end{array}$ & $\begin{array}{l}\text { lage al } \\
\text { re Ciçe } \\
\text { KEY } 3 \\
\text { om, } \\
+9021\end{array}$ & $\begin{array}{l}\text { d Liter } \\
\text { i Sokal } \\
7714 \\
7730\end{array}$ & $\begin{array}{l}\text { nture } S \\
\text { No:14 } \\
616\end{array}$ & & & \\
\hline
\end{tabular}


16.

Madd

e

17.

Madd

$\mathrm{e}$

18.

Madd

e

19.

Madd

e

20.

Madd

e

21.

Madd

\begin{abstract}
$+$
\end{abstract}
$+$

$+$

$+$

$+$

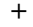

$+$

$+$

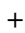

$+$

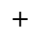

$+$
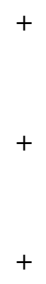

$+$

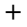

$+$

$+$

$+$

$+$

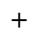

$+$
5

5

5

5

5

5

e

Uzman görüşlerinin yüksek düzeyde örtüşmesi, ilgili DPA’nın kapsam geçerliliğine sahip olduğunu göstermiştir.

DPA'nın güvenilirliği için 3 farklı alan uzmanının 30 farklı öğrencinin karşılıklı konuşma becerisi sınavını puanlandığı verilere ait güvenilirlik bulguları aşă̆ıda gösterilmiştir.

Tablo 10: Yabancı Dil Olarak Türkçe öğrenenler için B1 düzeyi yazma becerisi dereceli puanlama anahtarına yönelik güvenirlik bulguları

\begin{tabular}{|c|c|c|c|c|c|}
\hline \multirow{2}{*}{ Madde } & & \multirow{2}{*}{\multicolumn{2}{|c|}{$\begin{array}{l}\text { Puanlayicilar Arasi } \\
\text { Korelasyon (Intraclass } \\
\text { Correlation) }\end{array}$}} & \multicolumn{2}{|c|}{ \% 95 Güven Aralığı } \\
\hline & & & & Alt Sinır & Üst Sinır \\
\hline \multirow{2}{*}{ Başlık } & Tek Ölçümler & 973 & & .951 & .986 \\
\hline & Ortalama Ölçümler & .991 & & .983 & .995 \\
\hline \multirow{2}{*}{ Giriş } & Tek Ölçümler & .640 & & .451 & .793 \\
\hline & Ortalama Ölçümler & .842 & & .711 & .920 \\
\hline \multirow{2}{*}{ Mantık Sirası } & Tek Ölçümler & .753 & & .602 & .863 \\
\hline & Ortalama Ölçümler & .902 & & .820 & .950 \\
\hline \multirow{2}{*}{ Ayrıntı } & Tek Ölçümler & .755 & & .604 & .864 \\
\hline & Ortalama Ölçümler & .902 & & .821 & .950 \\
\hline \multirow{2}{*}{ Kişisel Görüş Yorum } & Tek Ölçümler & .727 & & .565 & .847 \\
\hline & Ortalama Ölçümler & .889 & & .796 & .943 \\
\hline \multirow{2}{*}{ Sonuç } & Tek Ölçümler & .700 & & .528 & .830 \\
\hline & Ortalama Ölçümler & .875 & & .770 & .936 \\
\hline \multirow{2}{*}{ Açık. Duru Anlatım } & Tek Ölçümler & .777 & & .636 & .877 \\
\hline & Ortalama Ölçümler & .913 & & .840 & .956 \\
\hline \multirow{2}{*}{ Kelimeyi Uygun } & Tek Ölçümler & .678 & & .499 & .817 \\
\hline & Ortalama Ölçümler & .863 & & .750 & .930 \\
\hline $\begin{array}{r}\text { Rumeli } \\
\text { Osmanağe }\end{array}$ & $\begin{array}{l}\text { DE Dil ve Edebiyat Araşttrn } \\
\text { Mahallesi, Mürver Çiçeği S } \\
\text { Kadıköy - İSTANBUL / TÜ } \\
\text { e-posta: editor@ } \\
\text { tel: +90 505 7958124, +90 }\end{array}$ & $\begin{array}{l}\text { Adres } \\
\text { Pergisi } \\
0: 14 / 8 \\
34714 \\
\text { e.com } \\
0616\end{array}$ & \multicolumn{3}{|c|}{$\begin{array}{l}\text { Address } \\
\text { RumeliDE Journal of Language and Literature Studies } \\
\text { Osmanağa Mahallesi, Mürver Ciçeği Sokak, No:14/8 } \\
\text { Kadıköy- ISTANBUL / TURKEY } 34714 \\
\text { e-mail: editor@rumelide.com, } \\
\text { phone: +90 505 7958124, +90 } 216773 \text { o } 616\end{array}$} \\
\hline
\end{tabular}


The impact of student - generated podcast formation processes on speaking and writing skills of learners of Turkish as a foreign language and their self-efficacy in these skills / O. K. Yorganc1 \& B. Baş (pp. 256-282)

\begin{tabular}{|c|c|c|c|c|}
\hline \multirow{2}{*}{ Kelime Doğru Yer } & Tek Ölçümler & .732 & .572 & .850 \\
\hline & Ortalama Ölçümler & .891 & .800 & .945 \\
\hline \multirow{2}{*}{ Kalıplaşmış İfade } & Tek Ölçümler & .852 & .749 & .921 \\
\hline & Ortalama Ölçümler & .945 & .899 & .972 \\
\hline \multirow{2}{*}{ Uygun Örnek } & Tek Ölçümler & .870 & .778 & .931 \\
\hline & Ortalama Ölçümler & .953 & .913 & .976 \\
\hline \multirow{2}{*}{ Özgün Yazım } & Tek Ölçümler & .689 & .514 & .824 \\
\hline & Ortalama Ölçümler & .869 & .760 & .933 \\
\hline \multirow{2}{*}{$\begin{array}{l}\text { Kelime Hazinesi } \\
\text { Seviye }\end{array}$} & Tek Ölçümler & .857 & .757 & .924 \\
\hline & Ortalama Ölçümler & .947 & .904 & .973 \\
\hline \multirow{2}{*}{ Farklı Tür Kelime } & Tek Ölçümler & .833 & .720 & .910 \\
\hline & Ortalama Ölçümler & .938 & .885 & .968 \\
\hline \multirow{2}{*}{ Atasözü Deyim } & Tek Ölçümler & .916 & .852 & .956 \\
\hline & Ortalama Ölçümler & .970 & .945 & .985 \\
\hline \multirow{2}{*}{ Kelime Doğru Yazım } & Tek Ölçümler & .667 & .485 & .810 \\
\hline & Ortalama Ölçümler & .857 & .738 & .927 \\
\hline \multirow{2}{*}{ İsim Çekim Eki } & Tek Ölçümler & .873 & .783 & .933 \\
\hline & Ortalama Ölçümler & .954 & .915 & .977 \\
\hline \multirow{2}{*}{$\begin{array}{l}\text { Farklı Uzunlukta } \\
\text { Cümle }\end{array}$} & Tek Ölçümler & .706 & .537 & .834 \\
\hline & Ortalama Ölçümler & .878 & .777 & .938 \\
\hline \multirow{2}{*}{ Söz Dizimi } & Tek Ölçümler & .677 & .498 & .816 \\
\hline & Ortalama Ölçümler & .863 & .748 & .930 \\
\hline \multirow{2}{*}{$\begin{array}{l}\text { Kelime Cümle } \\
\text { Bağlantı }\end{array}$} & Tek Ölçümler & .725 & .563 & .846 \\
\hline & Ortalama Ölçümler & .888 & .794 & .943 \\
\hline \multirow{2}{*}{ Fiil Çekim Eki } & Tek Ölçümler & .758 & .608 & .866 \\
\hline & Ortalama Ölçümler & .904 & .823 & .951 \\
\hline \multirow{2}{*}{ Toplam } & Tek Ölçümler & .941 & .896 & .969 \\
\hline & Ortalama Ölçümler & .980 & .963 & .990 \\
\hline
\end{tabular}

3 farklı alan uzmanı tarafından ayrı ayrı değerlendirilen 30 katılımcının sınavlarından elde edilen verilere göre hesaplanan değerlendiriciler arası tutarlılık katsayısının 0,98 olması ilgili DPA'nın güvenilir olduğunu göstermiştir.

Araştırmada Sallabaş (2013) tarafından geliştirilmiş ve yakın zamanda başka araştırmacılar tarafindan da kullanılmış “Türkçeyi Yabancı Dil Olarak Öğrenenler İçin Konuşma Öz Yeterlik Ölçeği” ile Büyükikiz (2012) tarafından geliştirilmiş ve yakın zamanda başka araştırmacılar tarafından da kullanılmış “Türkçeyi İkinci Dil Olarak Öğrenen Yabancllar İçin Yazma Becerisi Öz Yeterlik Ölçeği” geçerli ve güvenilir kabul edilip ilgili araştırmacıların izinleri alınarak kullanılmıştır.

\section{Verilerin toplanması ve analizi}

RumeliDE Dil ve Edebiyat Araștrmalarn Dergisi Osmanağa Mahallesi, Mürver Ciçeği Sokak, No:14/8

Kadıköy - İSTANBUL / TÜRKIYE 34714 e-posta: editor@rumelide.com

tel: $+905057958124,+902167730616$
Address

RumeliDE Journal of Language and Literature Studies

Osmanağa Mahallesi, Mürver Ciceği Sokak, No:14/8

Kadıköy - ISTANBUL / TURKEY 34714

e-mail: editor@rumelide.com,

phone: +90 505 7958124, +90 2167730616 
Yarı deneysel bu araştırmanın nicel verileri deneysel işlemin öğrencilerin bağımsız ve karşılıklı konuşma becerisi düzeyine, yazma becerisi düzeyine, konuşma ve yazma öz yeterlilik algllarına etkisini belirlemek için yapılan ön test ve son test ölçümleriyle toplanmış ve analiz edilmiştir.

Deneysel işlemde ön ve son test olarak kullanılan “Orta (B1-Bağımsız) Düzey Bağımsız Konuşma Türkçe Yeterlilik Sınavı” ile "Orta (B1-Bağımsız) Düzey Karşılıklı Konuşma Türkçe Yeterlilik Sınav”nın analizlerinde normal dağılım gösterip göstermeme durumları için Shapiro Wilk Testi, verilerin parametrik testin varsayımlarını karşılamama durumları için farklar üzerinden verileri karşılaştırma, parametrik test kullanımı koşullarının sağlandığı durumlar için ise bağımsız gruplarda T-Testi uygulanmıştır.

Deneysel işlemde ön ve son test olarak kullanılan "Orta (B1-Bağımsız) Düzey Yazma Türkçe Yeterlilik Sınavı"nın analizinde normal dağılım gösterip göstermeme durumları için Shapiro Wilk Testi, verilerin parametrik testin varsayımlarını karşılama durumları için de tekrarlayan ölçümlerde iki faktörlü ANOVA testi uygulanmıştır.

Deneysel işlemde ön ve son test olarak kullanılan "Konuşma Öz Yeterlilik" ile "Yazma Öz Yeterlilik" ölçeklerinin analizlerinde normal dağılım gösterip göstermeme durumları için Shapiro Wilk Testi, verilerin parametrik testin varsayımlarını karşılama durumları için ise tekrarlayan ölçümlerde iki faktörlü ANOVA testi uygulanmıştır.

\section{Deneysel işlem}

1. Deneysel işlem öncesinde çalışma grubu belirlenmiş ve Ylldız Teknik Üniversitesi TÖMER B1 düzeyi öğrencileri ile çalışlımasına karar verilmiştir.

2. Çalışma grubunun deney ve kontrol gruplarına ayrılabilmesi için kişisel bilgi formu ile konuşma ve yazma becerisi sınavları geliştirilmiştir.

3. Konuşma ve yazma becerisi sınavı puanlarına uygulanan Kendall Testi ve dağıtım korelasyonu ile deney ve kontrol grupları belirlenmiştir.

4. Ön ve son testte kullanılmak üzere geliştirilen konuşma ve yazma becerisi sinavları ile kullanım izinleri alınan konuşma ve yazma öz yeterlik ölçekleri ön test olarak uygulanmıştır.

5. Deney grubuna uygulama öncesinde altı hafta boyunca normal öğretime destek olarak oluşturacakları öğrenci yapısı podcast üretme görevleri detaylı bir şekilde açıklanmıştır.

6. Kontrol grubu öğrencilerine deney grubu öğrencilerinin altı hafta boyunca normal öğretime destek olacak üretecekleri podcastlere karşlık gelecek sayıda takip edilen öğretim seti konuşma ve yazma etkinliklerine ek konuşma ve yazma ödevleri verilmiştir.

6. Öğrencilerin bireysel olarak üretecekleri ilk ses yayını görevlerine takip edilen öğretim seti konularıyla da uyumuna dikkat edilerek yine öğrencilerle birlikte "Öz Yaşam Öyküsü” olarak karar verilmiştir.

7. Bireysel ses yayınlarını oluşturma takvimi ve basamakları öğrencilere detaylı bir şekilde açıklanmıştır.

8. Bireysel ses yayınlarının takvime ve basamaklara uygun şekilde üretilmesi sağlanmıştır.

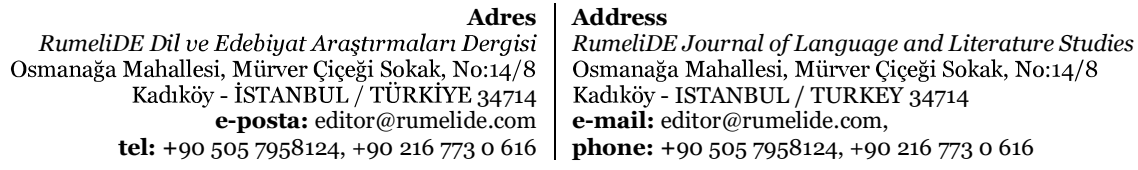

tel: $+905057958124,+902167730616$ 
The impact of student - generated podcast formation processes on speaking and writing skills of learners of Turkish as a foreign language and their self-efficacy in these skills / O. K. Yorganc1 \& B. Baş (pp. 256-282)

9. Öğrencilere ikinci ses yayını görevlerini gruplar hâlinde gerçekleştirecekleri, bunun için de grupların oluşturması gerektiği açıklanmış, öğrencilerin katılımıyla gerçekleştirilen kura sonucu gruplar oluşturulmuştur. 20 öğrencinin bulunduğu deney grubu sinıfindan her bir grupta 4 öğrenci olacak şekilde 5 farklı grup belirlenmiştir.

10. Öğrencilerle birlikte takip edilen öğretim seti konularına uygun olarak "1. Geçmişten Günümüze İletişim, 2. Yabancı Dil Olarak Türkçe, 3. Engellilerin Hayatlarını Kolaylaştıralım, 4. Türk Dizileri, 5. Bir Başarı Hikâyesi” beş farklı konu belirlenmiştir. Belirlenen 5 farklı konu öğrencilerle birlikte çekilen kura ile 5 farklı gruba dağıtılmıştır.

11. İkinci ses yayınlarını oluşturma takvimi ve basamakları öğrencilere detaylı bir şekilde açıklanmıştır.

12. İkinci ses yayınlarının takvime ve basamaklara uygun şekilde üretilmesi sağlanmıştır.

13. Üçüncü ve son podcast görevlerinin de grupla gerçekleştirileceği öğrencilerle paylaşılmış, son podcast yayını görevinde grubun ikinci ses yayınlarında başka bir grup tarafından seçilen bir konuyu seçerek yeniden üretim yapacağı açıklanmıştır.

14. Grupların son ses yayını görevleri için ikinci ses yayını konularından olmakla birlikte ikinci ses yayınlarında çalıştıklarından farklı bir konuyu kura ile seçmesi sağlanmıştır.

15. Son ses yayınlarını oluşturma takvimi ve basamakları öğrencilere detaylı bir şekilde açıklanmıştır.

16. Son ses yayınlarının takvime ve basamaklara uygun şekilde üretilmesi sağlanmıştır.

17. Altı haftalık uygulama sürecinin ardından deney ve kontrol gruplarına konuşma ve yazma becerisi sınavları ile konuşma ve yazma öz yeterlik ölçekleri son test olarak uygulanmıştır.

18. Sınav ve ölçeklerden elde edilen veriler ilgili istatistiksel programlarla analiz edilmiştir.

19. Analizler sonucu bulgular elde edilmiş, elde edilen bulgular yorumlanmıştır.

20. Araştırma nihayetinde ulaşılan sonuçlar ve bu sonuçlardan hareketle sunulan öneriler paylaşılmıştır.

\section{Araşturma ve yayın etiği}

Çalışmada "Yükseköğretim Kurumları Bilimsel Araştırma ve Yayın Etiği Yönergesi"nde belirtilen uyulması gereken kurallara uyulmuştur. İlgili yönergenin "Bilimsel Araştırma ve Yayın Etiğine Aykırı Eylemler” başlıklı ikinci bölümünde belirtilen eylemlerden hiçbiri ortaya çımamıştır.

\section{Etik Kurul İzni}

Kurul adı $=$ Yıldız Teknik Üniversitesi Sosyal ve Beşeri Bilimler Araştırmaları Etik Kurulu

Etik Kurulu Karar tarihi= 29.04.2021

Toplantı No= 2021/o2

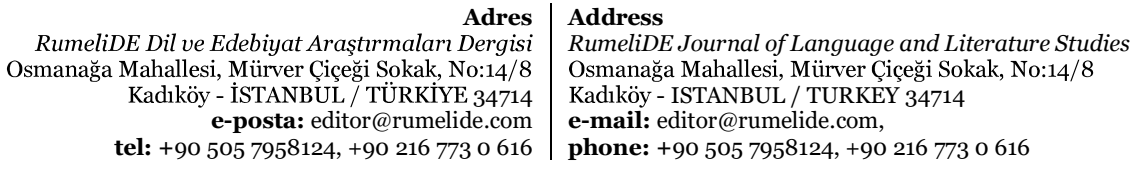




\section{Bulgular}

\section{Deneysel işlemin bağımsız konuşma başarısı üzerindeki etkisi}

Öncelikle deneysel işlemin Türkçeyi yabancı dil olarak öğrenen B1 kuru öğrencilerinin bağımsız konuşma başarısı üzerindeki etkisini belirlemek için verilerin normal dağılım gösterme durumu incelenmiştir.

Tablo 11: Bağımsız konuşma başarısı ön test ve son test puanlarının normal dağılım gösterme durumlarına ilişkin Shapiro Wilk testi sonuçları

\begin{tabular}{llll}
\hline Değişken & İstatistik & sd & $\mathrm{P}$ \\
\hline Bağımsız Konuşma Başarısı Öntest Puanı & .959 & 40 & .158 \\
Bağımsız Konuşma Başarısı Sontest Puanı & .935 & 40 & $.023^{*}$ \\
\hline
\end{tabular}

*p $<.05$

Tablo 11'den anlaşlacağı üzere Shapiro Wilk Testi analizinde bağımsız konuşma ön test verilerinin normal dağılım gösterdiği, son test verilerinin ise normal dağılım göstermediği belirlenmiştir. Bu şartlar altında deneysel işlemin etkisini test etmek için tekrarlayan ölçümlerde iki faktörlü ANOVA testi kullanmanın -gerekli koşullar sağlanamadığı için- mümkün olmadığı görülmüştür. Bu sebeple verilerin analizinde ön test ve son test arasındaki puan farklarının alını gruplar arasında bu farkların karşılaştırılması şeklinde bir yol tercih edilmiştir. Farklar üzerinden yapılacak analizde hangi testin kullanılacağına karar vermek için fark puanlarının normal dağılım gösterme durumlarına bakılmıştır.

Tablo12: Bağımsız konuşma başarısı öntest ve sontest puan farklarının normal dağılım gösterme durumlarına ilişkin Shapiro Wilk testi sonuçları

\begin{tabular}{llll}
\hline Değişken & İstatistik & sd & $\mathrm{P}$ \\
\hline Bağımsız Konuşma Başarısı Öntest-Sontest Farkı & .969 & 40 & .340 \\
\hline
\end{tabular}

Tablo 12'deki Shapiro Wilk Testi analizi sonuçlarından anlaşılacağı üzere bağımsız konuşma ön test ve son test puan farkları normal dağılım göstermektedir. Parametrik test kullanımı için gerekli koşullar sağlandığından verilerin analizinde bağımsız gruplarda T-Testi kullanılmıştır.

Tablo13: Bağımsız konuşma başarısı öntest ve sontest puan farklarının anlamlılığına ilişkin T-Testi sonuçları

\begin{tabular}{lllllll}
\hline Grup & $\mathrm{N}$ & $\mathrm{X}$ & $\mathrm{SS}$ & $\mathrm{t}$ & $\mathrm{sd}$ & $\mathrm{P}$ \\
\hline Deney & 20 & 21.280 & 9.424 & 3.035 & 38 & $.005^{*}$ \\
Kontrol & 20 & 13.760 & 5.831 & & & \\
\hline
\end{tabular}

Tablo 13'teki T-Testi sonuçları, deney ve kontrol grubunda yer alan öğrencilerin deneysel işlem öncesi ve sonrasında aldıkları bağımsız konuşma başarı puanları arasındaki farkların ait oldukları grup değiş̧kenine bağlı olarak anlamlı düzeyde farklılaştı̆̆ını göstermiştir $(\mathrm{t}(38)=3.035, \mathrm{p}<.05)$. Bu sonuca göre deney grubundaki öğrencilerin deneysel işlem öncesi ve sonrasında elde ettikleri puanlar arasındaki farkın, kontrol grubundaki öğrencilerin puanları arasındaki farktan istatistiksel olarak anlamlı düzeyde yüksek olduğu söylenebilir. Bu da deneysel işlemin bağımsız konuşma başarısını yükseltmede daha etkili olduğu şeklinde yorumlanabilir.

\section{Deneysel işlemin karşılıklı konuşma başarısı üzerindeki etkisi}

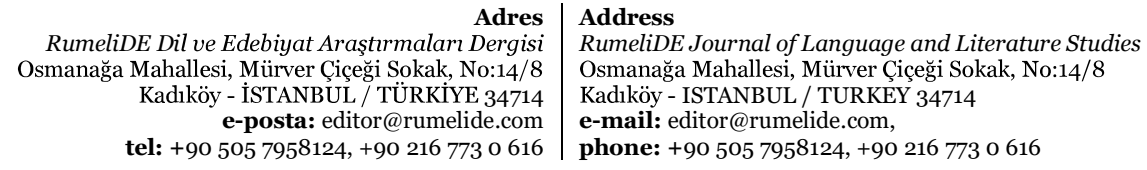


The impact of student - generated podcast formation processes on speaking and writing skills of learners of Turkish as a foreign language and their self-efficacy in these skills / O. K. Yorganc1 \& B. Baş (pp. 256-282)

Öncelikle deneysel işlemin yabancı dil olarak B1 düzeyinde Türkçe öğrenen öğrencilerinin karşılıklı konuşma başarısı üzerindeki etkisini belirlemek için verilerin normal dağılım gösterme durumu incelenmiştir.

Tablo14: Karşılıklı konuşma başarısı öntest ve sontest puanlarının normal dağılım gösterme durumlarına ilişkin Shapiro Wilk Testi sonuçları

\begin{tabular}{llll}
\hline Değişken & İstatistik & sd & P \\
\hline Karşılıkı Konuşma Başarısı Öntest Puanı & .935 & 40 & $.023^{*}$ \\
Karşılıkı Konuşma Başarısı Sontest Puanı & .920 & 40 & $.008^{*}$ \\
\hline
\end{tabular}

${ }^{*} \mathrm{p}<.05$

Tablo 14'ten anlaşılacağı üzere Shapiro Wilk Testi analizinde karşılıklı konuşma verilerinin her ikisinin de normal dağılım göstermediği belirlenmiştir. Bu şartlar altında deneysel işlemin etkisini test etmek için tekrarlayan ölçümlerde iki faktörlü ANOVA testi kullanmanın -gerekli koşullar sağlanamadığı içinmümkün olmadığı görülmüştür. Bu sebeple verilerin analizinde bağımsız konuşma beceri puanlarında yapıldığı gibi ön test ve son test arasındaki puan farklarının alınıp gruplar arasında bu farkların karşılaştırılması şeklinde bir yol tercih edilmiştir. Farklar üzerinden yapılacak analizde hangi testin kullanılacağına karar vermek için fark puanlarının normal dağılım gösterme durumlarına bakılmıştır.

Tablo15: Karşılıklı konuşma başarısı öntest ve sontest puan farklarının normal dağılım gösterme durumlarına ilişkin Shapiro Wilk testi sonuçları

\begin{tabular}{llll}
\hline Değişken & İstatistik & sd & $\mathrm{P}$ \\
\hline Karşılıklı Konuşma Başarısı Öntest-Sontest Farkı & .972 & 40 & .413 \\
\hline
\end{tabular}

Tablo 15 Shapiro Wilk Testi analizi sonuçlarından anlaşılacağı üzere karşıllklı konuşma ön test ve sontest puan farkları normal dağılım göstermektedir. Parametrik test kullanımı için gerekli koşullar sağlandığından verilerin analizinde bağımsız gruplarda T-Testi kullanılmıştır.

Tablo16: Karşılıklı konuşma başarısı öntest ve sontest puan farklarının anlamlılığına ilişkin T-Testi sonuçları

\begin{tabular}{lllllll}
\hline Grup & $\mathrm{N}$ & $\mathrm{X}$ & $\mathrm{SS}$ & $\mathrm{t}$ & $\mathrm{sd}$ & $\mathrm{P}$ \\
\hline Deney & 20 & 20.330 & 9.783 & 3.890 & 38 & $.000^{*}$ \\
Kontrol & 20 & 9.520 & 6.661 & & & \\
\hline
\end{tabular}

Tablo 16'daki T-Testi sonuçları, deney ve kontrol grubunda yer alan öğrencilerin deneysel işlem öncesi ve sonrasında aldıkları karşılıklı konuşma başarı puanları arasındaki farkların ait oldukları grup değişkenine bağlı olarak anlamlı düzeyde farklılaştığını göstermiştir $\left(\mathrm{t}_{(38)}=3.890, \mathrm{p}<.05\right)$. Bu sonuca göre deney grubundaki öğrencilerin deneysel işlem öncesi ve sonrasında elde ettikleri puanlar arasındaki farkın, kontrol grubundaki öğrencilerin puanları arasındaki farktan istatistiksel olarak anlamlı düzeyde yüksek olduğu söylenebilir. Bu da deneysel işlemin karşılıklı konuşma başarısını yükseltmede daha etkili olduğu şeklinde yorumlanabilir.

\section{Deneysel işlemin yazma başarısı üzerindeki etkisi}

Öncelikle deneysel işlemin Türkçeyi yabancı dil olarak öğrenen B1 kuru öğrencilerinin yazma başarısı üzerindeki etkisini belirlemek için verilerin normal dağılım gösterme durumu incelenmiştir.

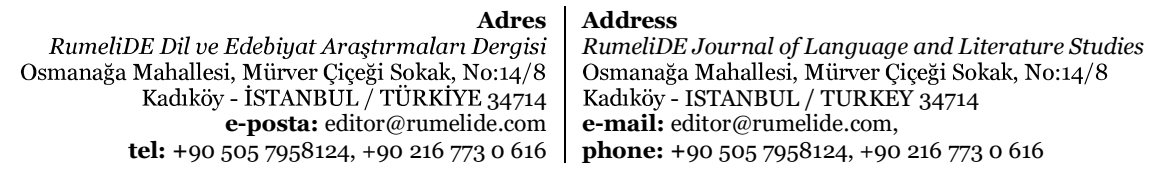


Tablo 17: Yazma başarısı öntest ve sontest puanlarının normal dağılım gösterme durumlarına ilişkin Shapiro Wilk testi sonuçları

\begin{tabular}{llll}
\hline Değişken & İstatistik & sd & $\mathrm{P}$ \\
\hline Yazma Başarısı Öntest Puanı &, 945 & 40 &, 052 \\
Yazma Başarısı Sontest Puanı &, 974 & 40 &, 478 \\
\hline
\end{tabular}

Tablo 17'deki sonuçlardan anlaşlacağı üzere verilerin parametrik testin diğer varsayımlarını da karşıllyor olması sebebiyle analize tekrarlayan ölçümlerde iki faktörlü ANOVA testi ile devam edilmiştir.

Tablo 18: Yazma başarısı öntest ve sontest puanlarının ortalama ve standart sapma değerleri

\begin{tabular}{lllllll}
\hline \multirow{2}{*}{ Grup } & Öntest & \multicolumn{5}{c}{ Sontest } \\
\cline { 2 - 7 } & $\mathrm{N}$ & $\mathrm{X}$ & $\mathrm{SS}$ & $\mathrm{N}$ & $\mathrm{X}$ & $\mathrm{SS}$ \\
\hline Deney Grubu & 20 & 71,90 & 15,30 & 20 & 82,49 & 12,80 \\
Kontrol Grubu & 20 & 71,19 & 11,47 & 20 & 75,10 & 12,43 \\
\hline
\end{tabular}

Deney ve kontrol grubunda yer alan öğrencilerin ön test ve son test puan ortalamaları ile standart sapmaları Tablo 18'de sunulmuştur. Tablodan anlaşılacağı gibi deney grubunda yer alan öğrencilerin deneysel müdahale öncesindeki yazma başarısı puan ortalamaları 71.90 iken deneysel müdahale sonrasında 82.49'a yükselmiştir. Kontrol grubunda ise deneysel müdahale öncesi ve sonrası puan ortalamaları sırasıyla 71.19 ve 75.10 olarak belirlenmiştir. Bu ortalamalar her iki grupta da ön test ve son test arasında geçen süre zarfında bir artış gerçekleştiğini göstermektedir.

Tablo 19: Yazma başarısı öntest ve sontest puanlarının ANOVA sonuçları

\begin{tabular}{lllllll}
\hline Varyansın Kaynağı & Kareler Toplamı & sd & $\begin{array}{l}\text { Kareler } \\
\text { Ortalaması }\end{array}$ & F & P & $\begin{array}{l}\text { Kismî } \\
\eta^{2}\end{array}$ \\
\hline Denekler Arası & 676,900 & 39 & & & & .32 \\
Grup(Birey/Grup) & 222.778 & 1 & 222.778 & 18.64 & $.000^{*}$ & .32 \\
Hata & 454.122 & 38 & 11.951 & & & \\
\hline Denekler İçi & 1728.875 & 40 & & & & .69 \\
Ölçüm (Öntest-Sontest) & 1051.975 & 1 & 1051.975 & $\mathbf{8 8 . 0 2}$ &. .000* $^{*}$ \\
Grup* Ölçüm & $\mathbf{2 2 2 . 7 7 8}$ & $\mathbf{1}$ & $\mathbf{2 2 2 . 7 7 8}$ & $\mathbf{1 8 . 6 4}$ & $\mathbf{. 0 0 0}^{*}$ & $\mathbf{. 3 2}$ \\
Hata & 454.122 & 38 & 11.951 & & & \\
Toplam & $\mathbf{2 4 0 5 . 7 7 5}$ & 79 & & & & \\
\hline
\end{tabular}

Tablo 19'daki sonuçlar dikkate alındığında iki farklı uygulamaya maruz kalan katılımcıların yazma başarılarının deneysel işlem öncesinden sonrasına anlamlı bir farklılık gösterdiği, yani farklı süreçlere maruz kalmak (deney ve kontrol olmak üzere iki farklı grupta bulunmak) ile tekrarlı ölçümler faktörlerinin yazma başarısı üzerindeki ortak etkisinin istatistiksel olarak anlamlı olduğu bulunmuştur $\mathrm{F}(1-38)=18.64, \mathrm{p}<.001$, kısmî $\eta 2.32$. Bu bulgu podcast üretimiyle desteklenmiş bir öğretime maruz kalmakla bu desteğin olmadığı bir öğretimsel içeriğe maruz kalmanın yabancı dil olarak Türkçe öğrenen B1 kuru öğrencilerinin yazma başarıları üzerindeki etkisinin farklı olduğunu göstermektedir. Yazma başarı puanlarında deney öncesine göre çok daha yüksek bir gelişim sağlayan podcast üretimiyle desteklenen öğretimsel içeriğin bu içerikle desteklenmemekle birlikte içeriğe karşllı gelecek sayıda etkinlik ödevleriyle desteklenen gruba kıyasla yazma başarısını geliştirmede daha etkili olduğu anlaşılmaktadır. İki grup arasındaki farkın grafik olarak karşlaş̧ırması Şekil ı'de gösterilmiştir.

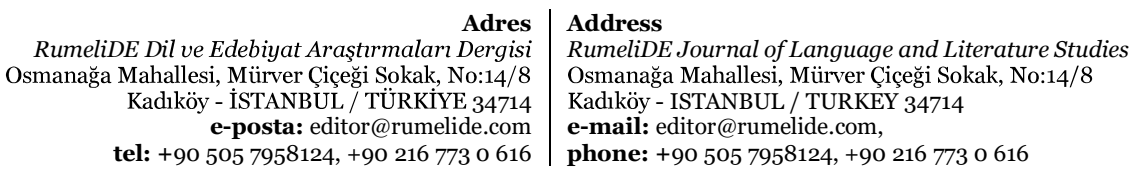


The impact of student - generated podcast formation processes on speaking and writing skills of learners of Turkish as a foreign language and their self-efficacy in these skills / O. K. Yorganc1 \& B. Baş (pp. 256-282)

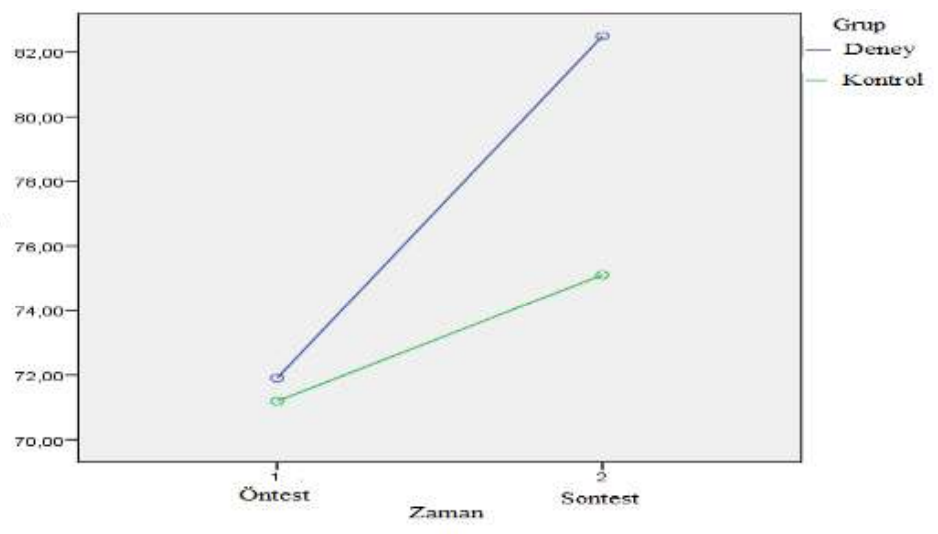

Şekil 1: Yazma başarısı öntest-sontest puanlarının görünümü

\section{Deneysel işlemin konuşma öz yeterlilik algıları üzerindeki etkisi}

Araştırma kapsamında yapılan deneysel müdahalenin yabancı dil olarak Türkçe öğrenen B1 kuru öğrencilerinin konuşma öz yeterlilikleri üzerindeki etkisini belirlemek için öncelikle elde edilen verilerin normal dağılım gösterme durumları incelenmiştir.

Tablo 2o: Konuşma öz yeterlilik algısı öntest ve sontest puanlarının normal dağılım gösterme durumlarına ilişkin Shapiro Wilk testi sonuçları

\begin{tabular}{llll}
\hline Değişken & İstatistik & sd & P \\
\hline Konuşma Öz Yeterlilik Algısı Öntest Puanı &, 972 & 40 &, 429 \\
Konuşma Öz Yeterlilik Algısı Sontest Puanı &, 975 & 40 &, 497 \\
\hline
\end{tabular}

Tablo 2o'de görüldüğü üzere yapılan Shapiro Wilk analizinde ön test ve son test verilerinin normal dağılım gösterdiği belirlenmiştir.

Verilerin parametrik testin diğer varsayımlarını da karşılıyor olması dolayısıyla analize tekrarlayan ölçümlerde iki faktörlü ANOVA testi ile devam edilmiştir. Araştırmanın deney ve kontrol gruplarında yer alan öğrencilerin ön test ve son test puan ortalamaları ile standart sapmaları Tablo 21'de gösterilmiştir.

Tablo 21: Konuşma öz yeterlilik algıları öntest ve sontest puanlarının ortalama ve standart sapma değerleri

\begin{tabular}{lllllll}
\hline \multirow{2}{*}{ Grup } & Öntest & \multicolumn{5}{c}{ Sontest } \\
\cline { 2 - 7 } & $\mathrm{N}$ & $\mathrm{X}$ & $\mathrm{SS}$ & $\mathrm{N}$ & $\mathrm{X}$ & $\mathrm{SS}$ \\
\hline Deney Grubu & 20 & 77.70 & 22.39 & 20 & 89.30 & 20.95 \\
Kontrol Grubu & 20 & 74.15 & 23.43 & 20 & 79.70 & 23.31 \\
\hline
\end{tabular}

Tablo 21'de görüldüğü gibi deney grubunda yer alan öğrencilerin deneysel müdahale öncesindeki konuşma öz yeterlilik puan ortalamaları 77.70 iken deneysel müdahale sonrasında ortalama 11 puanlık bir artışla bu puan 89.30 olmuştur. Kontrol grubunda ise deneysel müdahale öncesinde 74.15 olan puan ortalama 5 puanlık bir artışla 79.70'e ulaşmıştır. Bu ortalamalar deney grubunda daha fazla olmakla beraber her iki grupta da ön test ve son test arasında geçen süre zarfında bir artış yaşandığını göstermektedir.

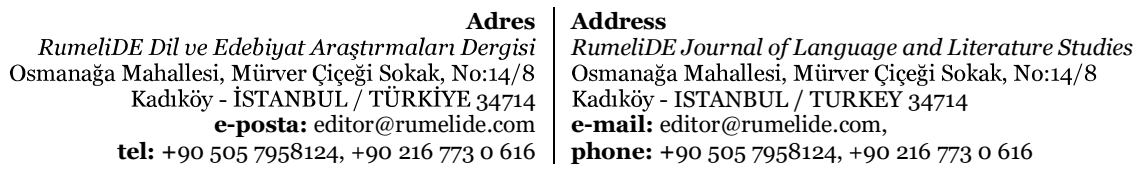


Tablo22: Konuşma öz yeterlilik algısı öntest ve sontest puanlarının ANOVA sonuçları

\begin{tabular}{|c|c|c|c|c|c|c|}
\hline Varyansın Kaynağı & Kareler Toplamı & sd & $\begin{array}{l}\text { Kareler } \\
\text { Ortalaması }\end{array}$ & $\mathrm{F}$ & $\mathrm{P}$ & $\begin{array}{l}\text { Kismî } \\
\eta^{2}\end{array}$ \\
\hline Denekler Arası & 38287.863 & 39 & & & & \\
\hline Grup(Birey/Grup) & 864.613 & 1 & 864.613 & .87 & .355 & .02 \\
\hline Hata & 37423.25 & 38 & 984.823 & & & \\
\hline Denekler İçi & 2857,500 & 40 & & & & \\
\hline Ölçüm (Öntest-Sontest) & 1470.612 & 1 & 1470.612 & 46.41 & $.000^{*}$ & .55 \\
\hline Grup*ö̈lçüm & 183.013 & $\mathbf{1}$ & 183.013 & $5 \cdot 77$ & $.021^{*}$ & .13 \\
\hline Hata & 1203.875 & 38 & 31.681 & & & \\
\hline Toplam & $41145 \cdot 363$ & 79 & & & & \\
\hline
\end{tabular}

Tablo 22'deki sonuçlar dikkate alındığında iki farklı uygulamaya maruz kalan katılımcıların konuşma öz yeterlilik algılarının deneysel işlem öncesinden sonrasına anlamlı bir farklılık gösterdiği, iki farklı grupta (deney ve kontrol) bulunmak ile tekrarlı ölçümler faktörlerinin konuşma öz yeterlilik algıları üzerindeki ortak etkisinin istatistiksel olarak anlamlı olduğu bulunmuştur $\left(\mathrm{F}_{(1-38)}=5.77, \mathrm{p}<.05\right.$, kısmî $\left.\eta^{2} .13\right) . \mathrm{Bu}$ bulgu podcast üretimiyle desteklenmiş bir öğretimsel sürece maruz kalmakla bu desteğin olmadığı bir öğretimsel içeriğe maruz kalmanın yabancı dil olarak Türkçe öğrenen B1 kuru öğrencilerinin konuşma öz yeterlilik algıları üzerindeki etkisinin farklı olduğunu göstermektedir. Konuşma öz yeterlilik algısı puanlarında deney öncesine göre çok daha yüksek bir gelişim sağlayan podcast üretimiyle desteklenen öğretimsel içeriğin bu içerikle desteklenmemekle birlikte içeriğe karşıllk gelecek sayıda etkinlik ve ödevlerle desteklenen gruba kıyasla konuşma öz yeterlilik algılarını yükseltmede daha etkili olduğu anlaşılmaktadır. İki grup arasındaki farkın grafik olarak karşılaştırması Şekil 2'de sunulmuştur.

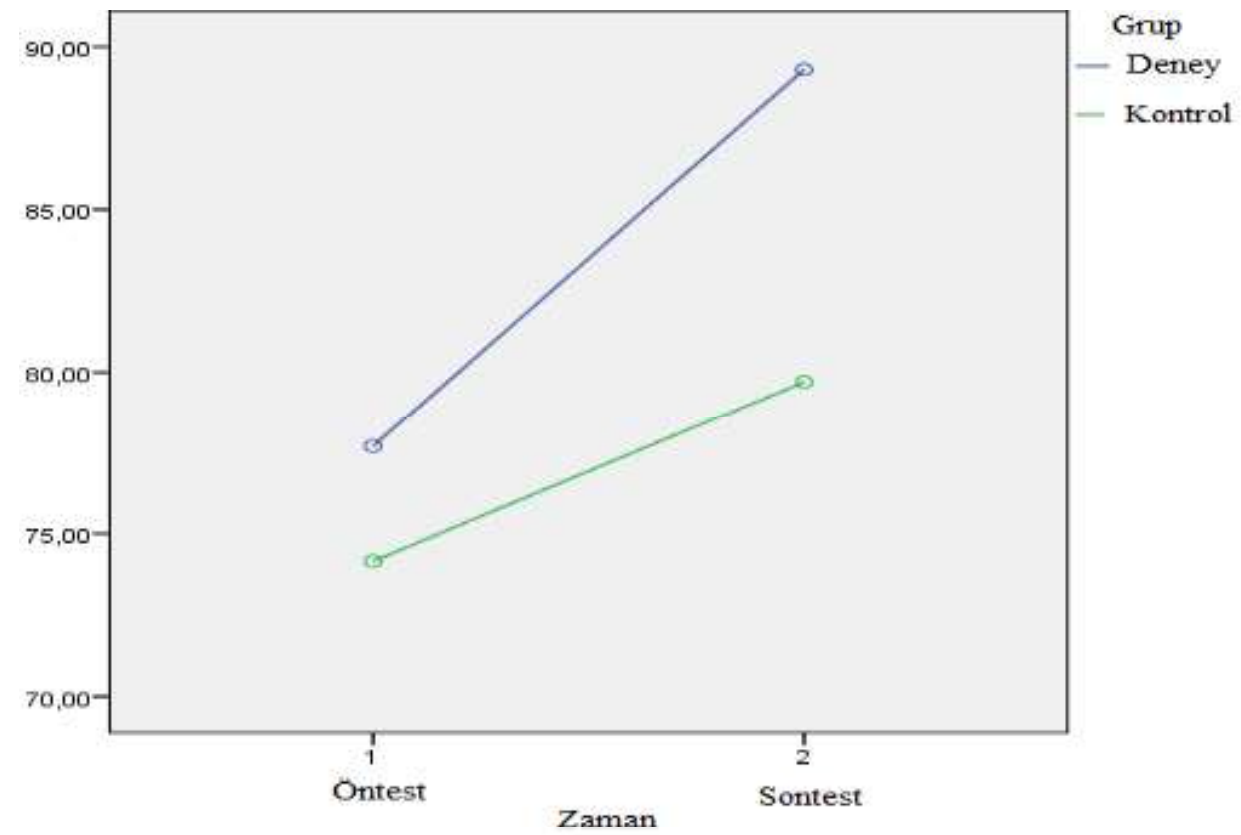

Şekil 2: Konuşma öz yeterlik algıları öntest-sontest puanlarının görünümü

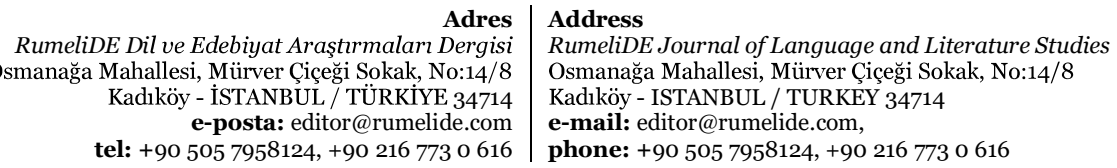


The impact of student - generated podcast formation processes on speaking and writing skills of learners of Turkish as a foreign language and their self-efficacy in these skills / O. K. Yorganc1 \& B. Baş (pp. 256-282)

\section{Deneysel işlemin yazma öz yeterlilik algıları üzerindeki etkisi}

Araştırma kapsamında yapılan deneysel müdahalenin yabancı dil olarak Türkçe öğrenen B1 kuru öğrencilerinin yazma öz yeterlilikleri üzerindeki etkisini belirlemek için öncelikle elde edilen verilerin normal dağılım gösterme durumları incelenmiştir.

Tablo 23: Yazma öz yeterlilik algısı öntest ve sontest puanlarının normal dă̆ılım gösterme durumlarına ilişkin Shapiro Wilk testi sonuçları

\begin{tabular}{llll}
\hline Değişken & İstatistik & sd & $\mathrm{P}$ \\
\hline Yazma Öz Yeterlilik Algısı Öntest Puanı & .977 & 40 & .562 \\
Yazma Öz Yeterlilik Algısı Sontest Puanı & .979 & 40 & .653 \\
\hline
\end{tabular}

Tablo 23’te görüldüğü üzere yapılan Shapiro Wilk analizinde ön test ve son test verilerinin normal dağılım gösterdiği belirlenmiştir.

Verilerin parametrik testin diğer varsayımlarını da karşıllyor olması dolayısıyla analize tekrarlayan ölçümlerde iki faktörlü ANOVA testi ile devam edilmiştir. Araştırmanın deney ve kontrol gruplarında yer alan öğrencilerin ön test ve son test puan ortalamaları ile standart sapmaları Tablo 24'tee gösterilmiştir.

Tablo 24: Yazma öz yeterlilik algıları öntest ve sontest puanlarının ortalama ve standart sapma değerleri

\begin{tabular}{lllllll}
\hline \multirow{2}{*}{ Grup } & Öntest & \multicolumn{5}{c}{ Sontest } \\
\cline { 2 - 7 } & $\mathrm{N}$ & $\mathrm{X}$ & $\mathrm{SS}$ & $\mathrm{N}$ & $\mathrm{X}$ & $\mathrm{SS}$ \\
\hline Deney Grubu & $2 \mathrm{~N}$ & 71,75 & 19,87 & 20 & 79,60 & 17,02 \\
Kontrol Grubu & 20 & 73,45 & 16,38 & 20 & 78,30 & 16,94 \\
\hline
\end{tabular}

Tablo 24'te görüldüğü üzere deney grubunda yer alan öğrencilerin deneysel müdahale öncesindeki yazma öz yeterlilik puan ortalamaları 71.75 iken deneysel müdahale sonrasında bu puan 79.60'a yükselmiştir. Kontrol grubunda ise deneysel müdahale öncesi ve sonrası puan ortalamaları sirasıyla 73.45 ve 78.30 olarak belirlenmiştir. Bu ortalamalar her iki grupta da ön test ve son test arasında geçen süre zarfında bir artış yaşandığını göstermektedir. Bununla birlikte deney grubundaki öğrencilerin puanlarındaki ortalama artışın (7.85 puan) kontrol grubundaki artıştan (4.85 puan) daha fazla olduğu da görülmektedir.

Tablo 25: Yazma öz yeterlilik algısı öntest ve sontest puanlarının ANOVA sonuçları

\begin{tabular}{|c|c|c|c|c|c|c|}
\hline Varyansın Kaynağı & Kareler Toplamı & sd & $\begin{array}{l}\text { Kareler } \\
\text { Ortalaması }\end{array}$ & $\mathrm{F}$ & $\mathrm{P}$ & $\begin{array}{l}\text { Kısmî } \\
\eta^{2}\end{array}$ \\
\hline Denekler Arası & 22998.950 & 39 & & & & \\
\hline Grup(Birey/Grup) & .800 & 1 & .800 & .01 & .971 & .00 \\
\hline Hata & 22998.150 & 38 & 605.214 & & & \\
\hline Denekler İçi & 1425.000 & 40 & & & & \\
\hline Ölçüm (Öntest-Sontest) & 806.450 & 1 & 806.450 & 53.43 & $.000^{*}$ & .58 \\
\hline Grup*ölçüm & 45.000 & $\mathbf{1}$ & 45.000 & 2.98 & .092 & .07 \\
\hline Hata & 573.550 & 38 & 15.093 & & & \\
\hline Toplam & 24423.950 & 79 & & & & \\
\hline $\begin{array}{r}\text { RumeliDE } \\
\text { Osmanağa Ma } \\
\mathrm{K} \\
\mathbf{t e l}\end{array}$ & $\begin{array}{l}\text { debiyat Araştrmaları } 1 \\
\text { Mürver Çiçeği Sokak, N } \\
\text { İSTANBUL / TÜRKIYY } \\
\text {-posta: editor@rumeli } \\
57958124,+90216773\end{array}$ & & $\begin{array}{l}\text { Address } \\
\text { RumeliDE Journal o } \\
\text { Osmanağa Mahallesi } \\
\text { Kadlköy - ISTANBUI } \\
\text { e-mail: editor@rum } \\
\text { phone: +90 } 505795\end{array}$ & $\begin{array}{l}\text { zge and } \mathrm{Li} \\
\text { Çiçeği Sol } \\
\text { EYY } 34714 \\
\text { n, } \\
90216773\end{array}$ & $\begin{array}{l}\text { ture Studies } \\
\text { No:14/8 } \\
16\end{array}$ & \\
\hline
\end{tabular}


${ }^{*} \mathrm{p}<.05$

Tablo 25'te sunulan sonuçlar dikkate alındığında iki farklı uygulamaya maruz kalan katılımcıların yazma öz yeterlilik algılarının deneysel işlem öncesinden sonrasına anlamlı bir farklılık göstermediği, yani deney ve kontrol olmak üzere iki farklı grupta bulunmak ile tekrarlı ölçümler faktörlerinin yazma öz yeterlilik algıları üzerindeki ortak etkisinin istatistiksel olarak anlamlı olmadığı bulunmuştur $\left(\mathrm{F}_{(1-38)}\right.$ $=2.98, p>.05$, kısmî $\eta^{2}$.07). İki grup arasındaki farkın grafik olarak karşılaştırması Şekil 3’te gösterilmiştir.

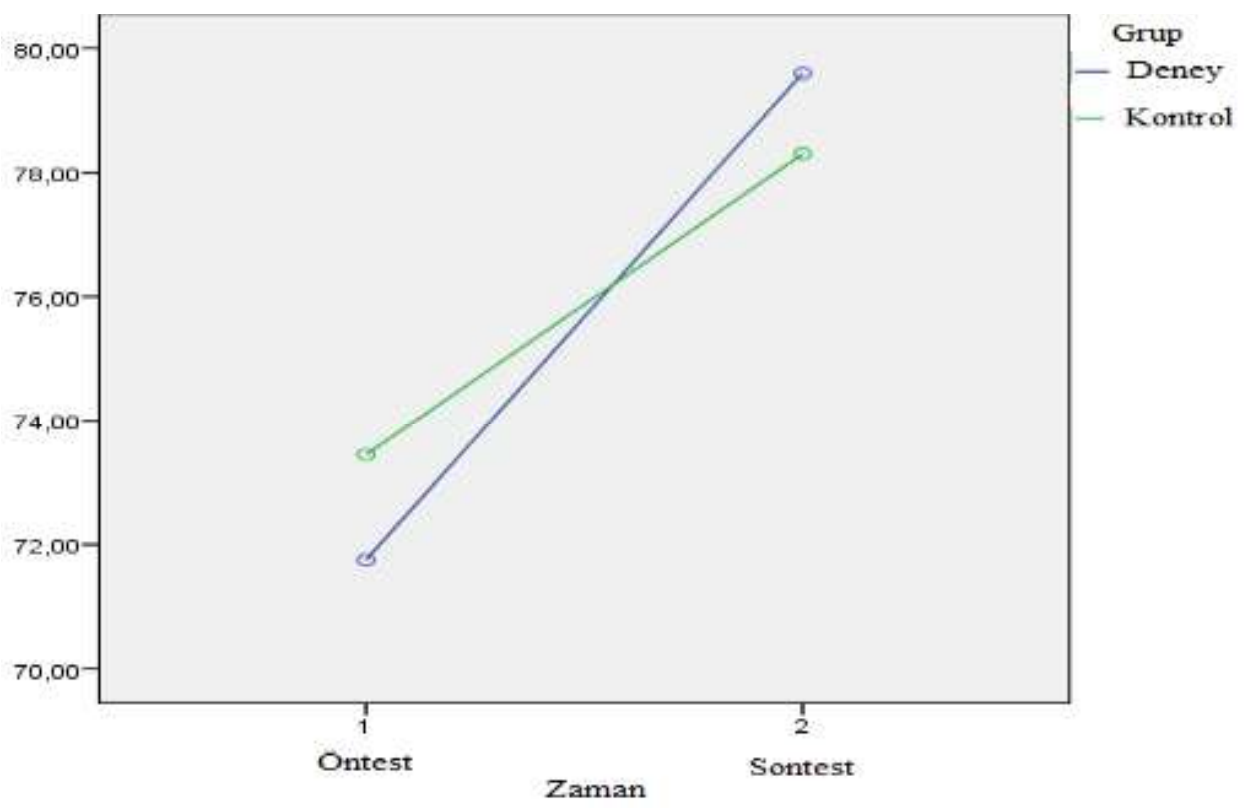

Şekil 3: Yazma öz yeterlik algıları öntest-sontest puanlarının görünümü

\section{Tartışma ve sonuç}

$\mathrm{Bu}$ araştırmada öğrenci üretimi ses yayınlarının yabancı dil olarak Türkçe öğrenen B1 düzeyindeki öğrencilerin yazma ve konuşma becerisi başarısı ile yazma ve konuşma öz yeterliliklerine etkisi ortaya konulmaya çalışılmıştır.

Araştırmada sesli yayın destekli öğretimsel içeriğe maruz kalan deney grubu öğrencilerinin kontrol grubu öğrencilerine göre deneysel işlem sonrası bağımsız konuşma başarısı puan ortalamalarının deneysel işlem öncesi bağımsız konuşma başarısı puan ortalarına göre daha fazla yükseldiği tespit edilmiştir. Farklı iki uygulamaya maruz kalan grupların bağımsız konuşma başarılarının deneysel işlem öncesinden sonrasına anlamlı farklılık gösterdiği, farklı uygulama süreçlerine maruz kalmanın bağımsız konuşma başarısı üzerinde istatistiksel açıdan anlamlı olduğu görülmüştür. Bu sonuç, sesli yayın üretimiyle desteklenmiş bir öğretime maruz kalmakla bu desteğin olmadığı bir öğretimsel içeriğe maruz kalmanın yabancı dil olarak Türkçe öğrenen B1 kuru öğrencilerinin bağımsız konuşma başarıları üzerindeki etkisinin farklı olduğunu göstermiştir. Elde edilen sonuç, öğrenci yapısı ses yayını kullanımının bağımsız konuşma eğitiminde yabancı dil olarak Türkçe öğrenenlerin bağımsız konuşma başarılarını yükseltebilecek yenilikçi bir teknolojik araç olduğunu ortaya koymaktadır.

\footnotetext{
Adres
RumeliDE Dil ve Edebiyat Araşttrmaları Dergisi Osmanağa Mahallesi, Mürver Ciçeği Sokak, No:14/8 Kadıköy - ISTANBUL / TÜRKIYE 34714 e-posta: editor@rumelide.com

Address

RumeliDE Journal of Language and Literature Studies Osmanağa Mahallesi, Mürver Çiçeği Sokak, No:14/8

Kadıköy - ISTANBUL / TURKEY 34714

e-mail: editor@rumelide.com,

tel: +90 505 7958124, +90 2167730616 phone: +90 505 7958124, +90 2167730616
} 
The impact of student - generated podcast formation processes on speaking and writing skills of learners of Turkish as a foreign language and their self-efficacy in these skills / O. K. Yorganc1 \& B. Baş (pp. 256-282)

Araştırmada sesli yayın destekli öğretimsel içeriğe maruz kalan deney grubu öğrencilerinin kontrol grubu öğrencilerine göre deneysel işlem sonrası karşlıklı konuşma başarısı puan ortalamalarının deneysel işlem öncesi karşılıklı konuşma başarısı puan ortalarına göre daha fazla yükseldiği tespit edilmiştir. Farklı iki uygulamaya maruz kalan grupların karşılıklı konuşma başarılarının deneysel işlem öncesinden sonrasına anlamlı farklılık gösterdiği, farklı uygulama süreçlerine maruz kalmanın karşılıklı konuşma başarısı üzerinde istatistiksel açıdan anlamlı olduğu görülmüştür. Bu sonuç, sesli yayın üretimiyle desteklenmiş bir öğretime maruz kalmakla bu desteğin olmadığı bir öğretimsel içeriğe maruz kalmanın yabancı dil olarak Türkçe öğrenen B1 kuru öğrencilerinin karşlıklı konuşma başarıları üzerindeki etkisinin farklı olduğunu göstermiştir. Elde edilen sonuç, öğrenci yapısı ses yayını kullanımının karşılıklı konuşma eğitiminde yabancı dil olarak Türkçe öğrenenlerin karşılıklı konuşma başarılarını yükseltebilecek yenilikçi bir teknolojik araç olduğunu ortaya koymaktadır.

Araştırmada sesli yayın destekli öğretimsel içeriğe maruz kalan deney grubu öğrencilerinin kontrol grubu öğrencilerine göre deneysel işlem sonrası yazma başarısı puan ortalamalarının deneysel işlem öncesi yazma başarısı puan ortalarına göre daha fazla yükseldiği tespit edilmiştir. Farklı iki uygulamaya maruz kalan grupların yazma başarılarının deneysel işlem öncesinden sonrasına anlamlı farklılık gösterdiği, farklı uygulama süreçlerine maruz kalmanın yazma başarısı üzerinde istatistiksel açıdan anlamlı olduğu görülmüştür. Bu sonuç, sesli yayın üretimiyle desteklenmiş bir öğretime maruz kalmakla bu desteğin olmadığı bir öğretimsel içeriğe maruz kalmanın yabancı dil olarak Türkçe öğrenen B1 kuru öğrencilerinin yazma başarıları üzerindeki etkisinin farklı olduğunu göstermiştir. Elde edilen sonuç, öğrenci yapısı ses yayını kullanımının yazma eğitiminde yabancı dil olarak Türkçe öğrenenlerin yazma başarılarını yükseltebilecek yenilikçi bir teknolojik araç olduğunu ortaya koymaktadır.

Araştırmada sesli yayın destekli öğretimsel içeriğe maruz kalan deney grubu öğrencilerinin kontrol grubu öğrencilerine göre deneysel işlem sonrası konuşma öz yeterlilik puan ortalamalarının deneysel işlem öncesi konuşma öz yeterlilik puan ortalarına göre daha fazla yükseldiği tespit edilmiştir. Farklı iki uygulamaya maruz kalan grupların konuşma öz yeterliliklerinin deneysel işlem öncesinden sonrasına anlamlı farklılık gösterdiği, farklı uygulama süreçlerine maruz kalmanın konuşma öz yeterlilikleri üzerinde istatistiksel açıdan anlamlı olduğu görülmüştür. Bu sonuç, sesli yayın üretimiyle desteklenmiş bir öğretime maruz kalmakla bu desteğin olmadığı bir öğretimsel içeriğe maruz kalmanın yabancı dil olarak Türkçe öğrenen B1 kuru öğrencilerinin konuşma öz yeterlilikleri üzerindeki etkisinin farklı olduğunu göstermiştir. Elde edilen sonuç, öğrenci yapısı ses yayını kullanımının konuşma eğitiminde yabancı dil olarak Türkçe öğrenenlerin konuşma öz yeterliliklerini yükseltebilecek yenilikçi bir teknolojik araç olduğunu ortaya koymaktadır.

Araştırmada sesli yayın destekli öğretimsel içeriğe maruz kalan deney grubu öğrencilerinin kontrol grubu öğrencilerine göre deneysel işlem sonrası yazma öz yeterlilik puan ortalamalarının deneysel işlem öncesi yazma öz yeterlilik puan ortalarına göre daha fazla yükseldiği tespit edilmiştir. Her ne kadar deney grubu puan ortalaması kontrol grubu puan ortalamasına göre daha fazla artış göstermiş olsa da grupların puan ortalamalarındaki artış miktarının yeterince yüksek olmadığı görülmüştür. Bu sebeple farklı iki uygulamaya maruz kalan grupların yazma öz yeterliliklerinin deneysel işlem öncesinden sonrasına anlamlı farklılık gösterdiği tespit edilmiş olsa da farklı uygulama süreçlerine maruz kalmanın yazma öz yeterlilikleri üzerinde istatistiksel açıdan da anlamlı olduğunu söylemek için yeterli sonuca ulaşılamamıştır. Bu sonuç, öğrenci yapısı ses yayını kullanımının yazma öz yeterliliği üzerindeki etkisinin daha iyi anlaşılabilmesi için farklı çalışmalar yapılması gerektiğini göstermektedir.

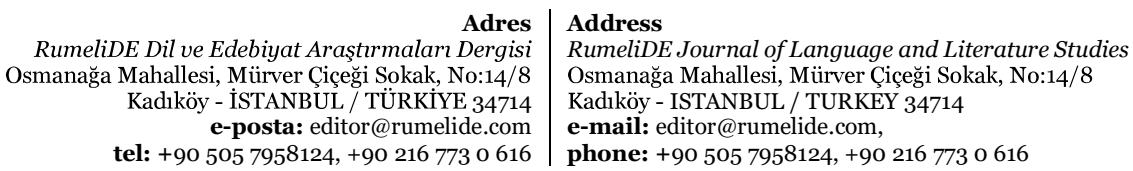


Berk (2019) çalışmasında dinleme becerisi başarısı bakımından deney grubundaki öğrencilerin kontrol grubundaki öğrencilerden daha başarılı olduğunu tespit edip ses yayınlarının Türkçenin yabancı dil olarak öğretiminde dinleme eğitiminde kullanılabilecek ve dinlediğini anlama başarısını yükseltebilecek etkili bir araç olduğunu, deney grubundaki öğrencilerin kaygı düzeylerinin kontrol grubundaki öğrencilerin kaygı düzeylerinden daha düşük olsa da deney grubu lehine gözlenen bu sonucun istatistiksel bakımdan anlamlı sayılabilecek düzeyde olmadığını ifade etmektedir. İlgili araştırmada her ne kadar bu çalışmadan farklı olarak dinleme ve kaygı çalışılmış olsa da dinleme kaygısına yönelik istatistiksel açıdan anlamlı sayılabilecek bir sonuca ulaşılamamış olması bu çalışmadaki yazma öz yeterlilik inançlarında deney grubu lehine anlamlı farklılık olsa da istatistiksel açıdan anlamlı sayılabilecek düzeyde bir farklılık olmadığı sonucuyla örtüşmektedir.

Koçak (2017) çalışmasından elde ettiği verilerden hareketle öğrencilerin öğrenen ses yayını geliştirmeyi tecrübe etmeden önceki konuşma becerisi seviyelerine kıyasla öğrenen ses yayını oluşturduktan sonra İngilizce konuşma becerilerini önemli ölçüde geliştirdiklerini, öğrenci üretimi ses yayınlarının teknoloji temelli tamamlayıcı bir yenilikçi öğretim aracı olarak kullanıldığında öğrencilerin konuşma becerilerini geliştirmelerine olanak sağladığı için EFL öğrencilerinin konuşma becerilerine yönelik potansiyel faydası olduğunu belirtmektedir. İlgili araştırma bu yönü ile yabancı dil olarak Türkçe öğretiminde ses yayını kullanımının üretici dil becerilerine etkisinin araştırıldığı bu çalışmadan elde edilen sonuçlarla benzerlik göstermektedir.

Uluslararası bazı araştırma sonuçları da bu çalışmadaki sonuçlara benzer ve bu çalışmadaki sonuçları destekler niteliktedir. Farangi ve diğerleri (2016) İngilizcenin yabancı dil olarak öğretimi üzerine yapmış oldukları araştırmalarında ses yayınlarının EFL öğrenenlerinin konuşma becerilerini geliştirmelerine yardımcı olan yararlı bir eğitim aracı olduğunu işaret etmektedirler. Roesell-Aguilar (2013) ve Stockwell (2010) ses yayınlarının dil öğrenenlere çeşitli görsel-işitsel kaynaklar sağlamanın yanında dil öğretiminin amaçlarından biri olan etkileşim için önemli bir firsat sunduğunu, öğrenenlere sürece dâhil olma imkânı sunması bakımından etkileşimi arttırdığını, sınıf içinde ve dışında grupla birlikte çalışma fırsatı sunmasıyla da yine etkileşim için zemin hazırladığını ileri sürmektedirler.

Daha evvel yapılmış uluslararası çalışmalarda öğrenci yapısı ses yayınlarının öğretime destek amacıyla kullanımının önemli yararlar sağlayacağı ve öğrenci etkileşimini önemli ölçüde arttıracağı yönündeki sonuçlar üzerine yapılan vurguların Türkçenin yabancı dil olarak öğretimi üzerine gerçekleştirilen bu araştırmada benimsenen ses yayınlarını öğretime destek olarak kullanma ve grupla birlikte çalışma ilkelerini destekler ve doğrular mahiyette olması çalışmanın önemini bir kez daha ortaya koymaktadır.

Araştırma sonucunda dil öğretimini öğrenci yapısı ses yayınlarıyla desteklemenin öğrencilerin konuşma ve yazma becerisi başarılarını arttırdığı görülmüştür. Yabancı dil olarak Türkçe öğretimi alanında çalışanların öğrencilerine temel öğretime destek olacak şekilde ses yayınları ürettirerek öğrenci yapısı ses yayınlarını etkili bir konuşma ve yazma eğitimi gerçekleştirmede yenilikçi teknolojik bir araç olarak kullanabileceği düşünülmektedir.

Araştırma; ana dili ve yabancı dil olarak Türkçe öğretiminde yenilikçi teknolojik bir araç olan öğrenci yapısı ses yayınlarının konuşma ve yazma becerisi başarıları ile konuşma ve yazma öz yeterlik algıları üzerine yapılmış ilk ve tek çalışma olması dolayısıyla araştırmacıların gelecekte yapacakları çalışmalara ışı tutabileceği düşünülmektedir.

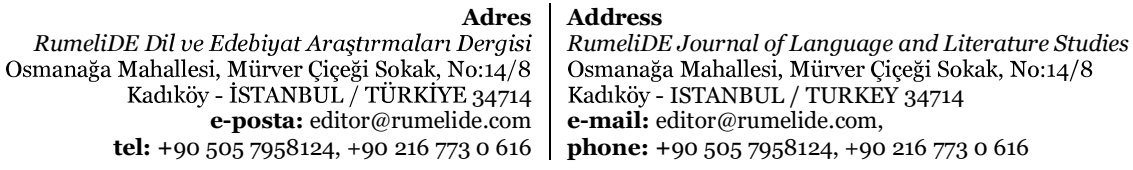

RumeliDE Dil ve Edebiyat Araşttrmaları Dergisi e-posta: editor@rumelide.com tel: +90 505 7958124, +90 2167730616 
Ayrıca gerek ses yayınları üzerine yurt içinde yapılan sınırlı sayıdaki çalışmada gerekse yurt dışında gerçekleştirilen çalışmalarda ses yayını türlerinden öğretmen yapısı veya hazır ses yayınları ile dinleme becerisi üzerine yoğunlaşıldı̆̆ı, öğrenci üretimi ses yayınları ile bu yayınların konuşma ve yazma becerilerine etkisi üzerine neredeyse hiç çalışma yapılmadığı dikkate alındığında bu araştırmanın öğrenci yapısı ses yayınları ve bu yayınların konuşma ve yazma becerilerine etkisinin gelecekte araştırılacağı yeni çalı̧̧malara yol gösterici olacağı düşünülmektedir.

\section{Kaynakça}

Antalyalı, Ö. L. (2006). Kümeleme analizi (cluster analysis). İçinde Ş. Kalaycı (Ed.), spss uygulamalı çok değişkenli istatistik teknikleri (ss. 349-376). Asil Yayın Dağıtım.

Berk, R. R. (2019). Yabancı dil olarak Türkçe öğretiminde elektronik dinletilerin dinlediğini anlama başarısı ve dinleme kaygısına etkisi [Doktora tezi]. Gazi Üniversitesi Eğitim Bilimleri Enstitüsü.

Büyükikiz, K. K. (2012). Türkçeyi ikinci dil olarak öğrenen yabancılar için yazma becerisi öz yeterlilik ölçeğinin geliştirilmesi: geçerlilik ve güvenilirlik çalışması. Mustafa Kemal Üniversitesi Sosyal Bilimler Enstitüsü Dergisi, 9(12), 69-80.

Büyüköztürk, Ş. (2008). Sosyal bilimler için veri analizi el kitabı. Pegem A Yayıncılık.

Ceyhan, C., \& Karakaş, R. (2019). Yabancılara Türkçe öğretiminde kullanılacak yapılandırılmış bir podcastte bulunması gereken özellikler. Karadeniz Uluslararası Bilimsel Dergi, 44, 335-349.

Farangi, M. R., Nejadghanbar, H., Askary, F., \& Ghorbani, A. (2016). The effects of podcasting on efl upper-1ntermediate learners' speaking skills. CALL-E, 76(2), 1-18.

Foulger, T. S., Graziano, K. J., Schmidt-Crawfor, D. A., \& Slykhuis, D. A. (2017). Teacher educator technology competencies. Jl. of Technology and Teacher Education, 25(4), 413-448.

Framework for 21st Century Learning. (2019). BattelleforKids. http://static.battelleforkids.org/documents/p21/P21_Framework_Brief.pdf

Koçak, A. (2017). Developing speaking skills via creating and using learner podcasts in English language classes [Doktora tezi]. Hacettepe Üniversitesi, Eğitim Bilimleri Enstitüsü.

Kooten, J. van, \& Bie, T. de. (t.y.). How to make an educational podcast? Tips and tricks for your first educational podcast version 2.o. Leiden University Centre for Innovation. Geliş tarihi o6 Temmuz 2020, gönderen https://www.centre4innovation.org/

New London Group. (1996). A pedagogy of multiliteracies: designing social futures. İçinde B. Cope \& M. Kalantis (Ed.), Multiliteracies: Literacy learning and the design of social futures (ss. 10-30). Macmillan.

OECD. (2008). 21st Century Skills: How can you prepare students for the new global economy. OECD. oecd.org/site/educeri21st/40756908.pdf

Rosell-Aguilar, F. (2013). Podcasting for language learning through İtunes u: the learner's view. Language Learning \& Technology, 17(3), 74-93.

Sallabaş, M. E. (2013). Türkçeyi yabancı dil olarak öğrenenler için konuşma öz yeterlik ölçeği: geçerlilik ve güvenirlilik çalışması. Dumlupınar Üniversitesi Sosyal Bilimler Dergisi, 36, 261-270.

Stockwell, G. (2010). Using mobile phones for vocabulary activities: examining the effect of the platform. Language Learning \& Technology, 14(2), 95-110.

Şendağ, S., Gedik, N., Caner, M., \& Toker, S. (2017). Mobil-yoğun-podcast dinlemenin İngilizce öğretmen adaylarının dinleme, konuşma ve eleştirel düşünme becerilerine etkisi. Eğitim Teknolojisi Kuram ve Uygulama, 7(2), 94-122.

Toker, T., Akgün, E., Cömert, Z., \& Edip, S. (2021). Eğitimciler için dijital yeterlilik ölçeği: uyarlama, geçerlik ve güvenirlik çalışması. Millî Eğitim, 50(230), 301-328.

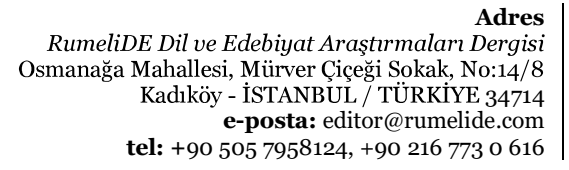

tel: +90 $5057958124,+902167730616$
Address

RumeliDE Journal of Language and Literature Studies

Osmanağa Mahallesi, Mürver Çiçeği Sokak, No:14/8

Kadıköy - ISTANBUL / TURKEY 34714

e-mail: editor@rumelide.com,

phone: +90 505 7958124, +90 2167730616 